\title{
Turonian flint economy in the easternmost Magdalenian: new data from Stare Baraki, site 1 (eastern Poland)
}

\author{
Tadeusz Wiśniewski ${ }^{1}$ (D) $\cdot$ Maciej T. Krajcarz $^{2}$ (D) $\cdot$ Karol Standzikowski $^{3}$ (D)
}

Received: 5 July 2020 / Accepted: 22 October 2020 / Published online: 23 November 2020

(C) The Author(s) 2020

\begin{abstract}
Magdalenian communities exploited mostly local and regional good-quality lithic raw materials. In south-eastern Poland, being the easternmost fringe of the Magdalenian range, Turonian grey flint had a particular importance. Outcrops of this raw material occur both at the west and at the east sides the Vistula River Gorge. The varieties from the eastern area (called here "eastern Turonian flint" or ETF) are common among inventories of the Magdalenian sites situated to west of the Vistula river. This fact points toward the frequent penetration of the ETF outcrop area by those societies. However, no Magdalenian sites were known directly from the ETF deposit area, and this gap in knowledge restricted further understanding of the character and diversity of Magdalenian activity there. Therefore, in this paper, we present the results of searching for Magdalenian sites within the ETF outcrop zone. Applied methodology included study of the archive archaeological materials, followed by detail survey and excavation of the selected site-Stare Baraki 1. This site documents a short stay or multiple stays of Magdalenian people, who were focused on Turonian flint knapping. Lithic inventory records collecting of several local flint varieties at the distance up to around $20 \mathrm{~km}$ from the site, followed by almost all stages of flint working. The material from Stare Baraki is the first known and currently the only trace of the Magdalenian people inside the zone of Turonian flint deposits on the right bank of the Vistula river. The study in Stare Baraki delivered new data for the reconstruction of territory exploitation strategies used in the easternmost Magdalenian.
\end{abstract}

Keywords Archaeology $\cdot$ Late Upper Palaeolithic $\cdot$ Lithic analysis $\cdot$ Technology $\cdot$ Central Europe

\section{Introduction}

Research into strategies for acquisition, distribution and usage of raw materials is an important source of information on

Tadeusz Wiśniewski

krzem7@o2.pl

Maciej T. Krajcarz

mkrajcarz@twarda.pan.pl

Karol Standzikowski

karol.standzikowski@poczta.umcs.lublin.pl

1 Institute of Archaeology, Nicolaus Copernicus University in Torun, Szosa Bydgoska 44/48, 87-100 Toruń, Poland

2 Institute of Geological Sciences, Polish Academy of Sciences, Twarda 51/55, 00-818 Warszawa, Poland

3 Institute of Earth and Environmental Sciences, Maria Curie-Skłodowska University, Al. Kraśnicka 2c, 20-031 Lublin, Poland organisation of land use by hunter-gatherer groups in the Upper and Late Palaeolithic (e.g. Rensink 1995; Fisher and Eriksen 2002; Sulgostowska 2005). By analysing the contribution of individual raw materials at particular sites and the range of their distribution, we achieve possibilities to reconstruct Palaeolithic migration trails, methods of land exploitation and potential contacts between individual groups of hunter-gatherers (Maier 2012; Floss 2014). Information on mobility strategies adopted by past hunter-gatherers can also be obtained by establishing their systems of selecting and processing raw materials (Wiśniewski et al. 2012a). This methodology is widely used in the study of Magdalenian, a unit of Late Upper Palaeolithic which ranged from Western to Central-Eastern Europe.

In general, Magdalenian communities exploited mostly local and regional good quality lithic raw materials, the outcrops of which were situated usually in the vicinity of their main settlement centres, up to $20 \mathrm{~km}$ (e.g. Leesch et al. 2012: p. 205; Street et al. 2012: p. 243; Wiśniewski et al. 2012b; Maier 2015; Olive et al. 2019). However, methods of exploitation of 
a territory, differences in location of settlements, and methods of raw materials management, varied between individual regional groups of the Magdalenian (Rensink 1995; Valoch 2009; Maier 2012, 2015; Połtowicz-Bobak 2013). This is well visible in the easternmost Magdalenian, so-called "eastern province of the Magdalenian" as distinguished by M. Połtowicz-Bobak (Połtowicz-Bobak 2013; Bobak and Połtowicz-Bobak 2014, 2018) or the "Polish-Moravian group" of Central European Magdalenian defined by A. Maier (Maier 2015, 2-4, Fig. 1.2).

According to current knowledge, the upland zone of southeastern Poland constituted an eastern border of the Magdalenian range in Europe (Połtowicz-Bobak 2013, 2016; Wiśniewski 2015; Wiśniewski et al. 2017). The first Magdalenian settlement in Poland was connected with middle Magdalenian phase, best recorded in Maszycka Cave (18.5-17.5 ky BP) (Kozłowski et al. 2012). The major development and expansion of the easternmost Magdalenian coincided with late Magdalenian phase, around 16.5-13.1 ky BP (Bobak and Poltowicz-Bobak 2014; Bobak et al. 2017). Generally, dates obtained for Magdalenian sites in south-eastern Poland indicate a range between the Greenland Stadial 2 (GS-2a according to stratigraphic subdivision by Rasmussen et al. 2014, or Oldest Dryas) and the Greenland Interstadial 1d (GI-1d, or Allerød). In most terminologies (e.g., Maier 2015), the chronological ranges of Magdalenian are more restricted, and sites dated to Allerød are usually attributed to the post-Magdalenian units (Late Palaeolithic). However, the subdivision and time ranges of the easternmost Magdalenian have not been fully recognised yet. It is considered that the late phase of classic Magdalenian could have survived in Polish lands even until the Allerød (GI-1c-b) (Poltowicz-Bobak 2016). For example, at Wierzawice site, radiocarbon dates clearly point to the Allerød (GI-1c) but the assemblage bears all the classical features of a Magdalenian inventory (Bobak et al. 2017).

The distribution of sites associated with the late phase of Central European Magdalenian indicates that settlements were located mostly in the proximity of large rivers and geological deposits of high-quality lithic raw materials (Maier 2015: pp. 86-87, Fig. 6.3-4). Certainly, these preferences were influenced by both environmental and cultural factors (Whallon 2006). The sites of the easternmost Magdalenian are clustered around the interfluve of two large rivers: Vistula and San. The majority of sites in this region are located in loess uplands, and likewise in the entire Central European Magdalenian, in the proximity of river valleys and outcrops of lithic raw material. Among the regional siliceous raw materials, two types of very good quality had a particular importance in Magdalenian: Upper Jurassic chocolate flint and Turonian grey flint.

\section{Geology of Turonian flint}

Turonian in central-eastern Poland represents the final stage of Albian-Turonian transgression, followed by the stabilisation of relatively shallow sea, temporarily or locally interrupted by the shallowing events (Pożaryski 1948; Walaszczyk and Remin 2015). Turonian rocks in the region are variable marine carbonate deposits, mostly limestones (marly, siliceous, detrital and reef), gaizes and marls, all of them often accompanied by silicites (Pożaryski 1948; Złonkiewicz 1994; Włodek and Gaździcka 2009). The Turonian silicites, also called Turonian grey flints, are developed in two facies (Michniak 1989). First one includes nodular cherts, i.e. the intra-bed concretions of siliceous material, representing the epi-sedimentary diagenetic replacement of a carbonate parent material by silica. They are developed either in a form of well-separated ellipsoidal nodules, or weakly developed nests of siliceous material, the latter often small and branched, are known in Polish literature as "czerty." Second facies is a bedded chert, i.e. the syn-sedimentary inter-bed layers of silicite, occurring as lenses or secondarily deformed boudinage between the beds of carbonate rock. The bedded chert facies is less common, and is known until now only from quarries in Karsy and Janików (Budziszewski and Grużdź 2014; Michniak 1989). In archaeological literature, most of these regional varieties of Turonian chert are called "flints" (Polish "krzemień"), due to their good or very good quality and knapping properties, although most of them do not fit to the widely accepted geological definition of flint (Přichystal 2010).

Outcrops of Turonian rocks occur at the central and northern part of Meta-Carpathian upland zone (Geological Map of Poland without Cenosoic Deposits, 1:1 000 000. 2000), i.e.: at the north-eastern margin of the Holy Cross Mts.; in the entrenched canyon of the Vistula river (so-called "Lesser Poland Vistula River Gorge", or Polish "Małopolski Przełom Wisły", including the best outcrops of the Upper Cretaceous in the region); in the eastern part of the Lublin Upland; and isolated outcrops are in the Nida Basin. Turonian strata continue to the north and east, however, under a thick cover of younger rocks. In the outcrop zone, Turonian is also usually covered by Neogene and/or Quaternary deposits, so the Turonian rocks are directly accessible at the limited area, mostly at steep slopes in the river valleys and gorges.

Weakly developed nodular cherts are common throughout entire Turonian in the region, while well-developed nodules and bedded cherts occur in the restricted area of so-called Tarłów Graben (Michniak 1989), where detrital and reef limestones dominate (Walaszczyk and Remin 2015). These deposits occur within around $250 \mathrm{~km}^{2}$ zone, both at the west and east side of the Vistula river (Fig. 1a-c), and are the source of all known Turonian flints which were used as raw materials in prehistory.

\section{The use of Turonian flint by the Magdalenian communities}

The majority of Magdalenian sites where Turonian raw materials (particularly the Świeciechów variety) have been 


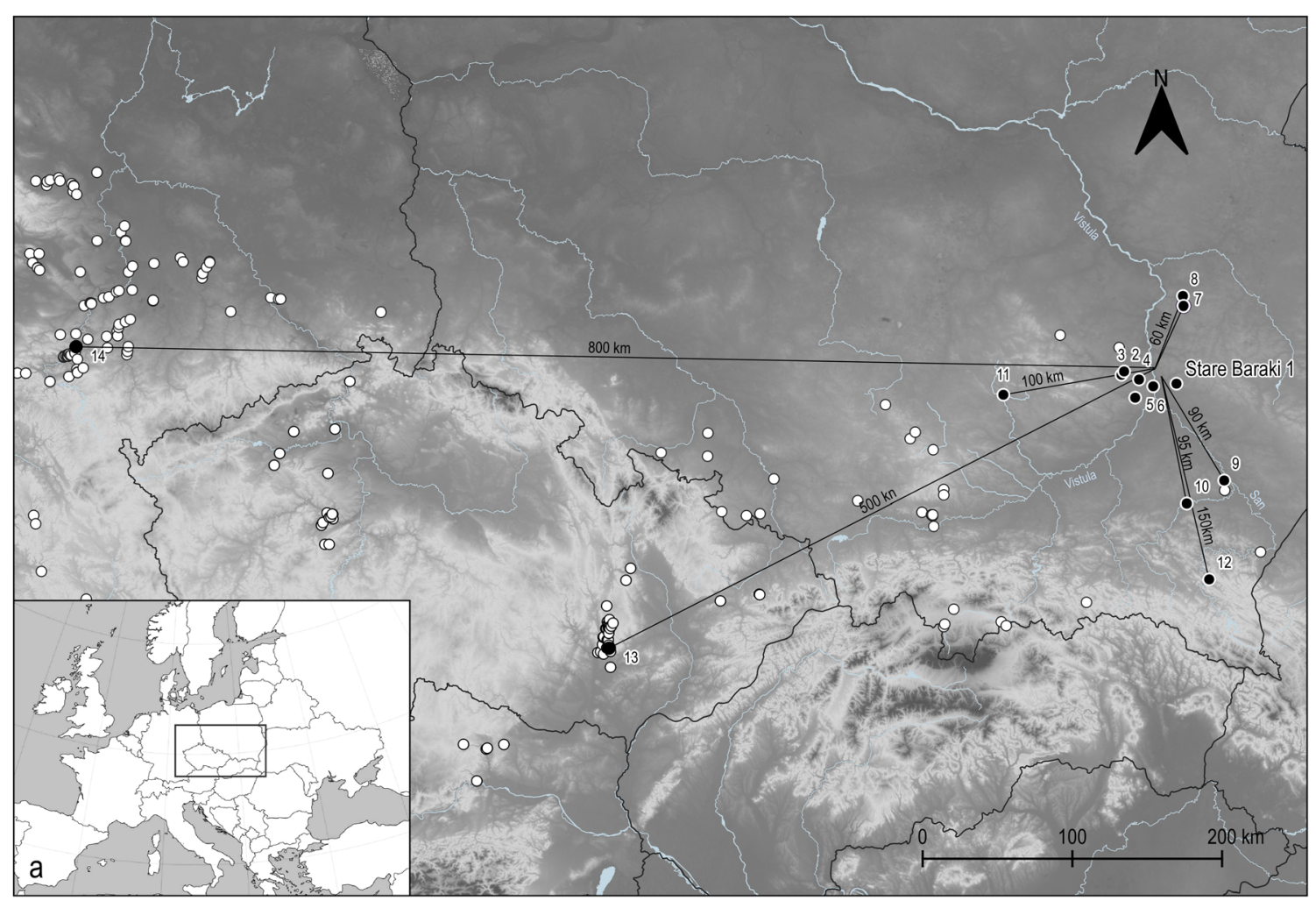

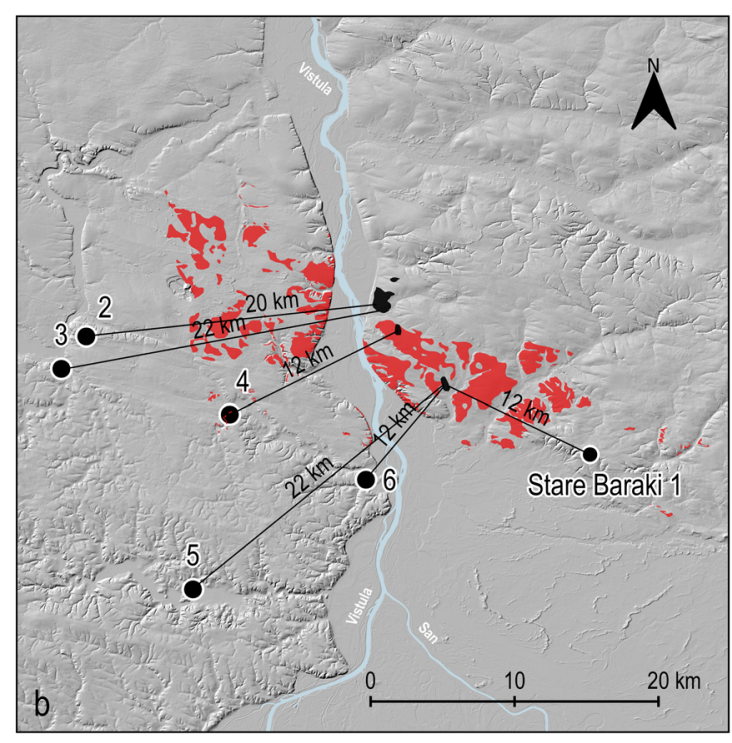

Fig. 1 a Magdalenian sites with artefacts made from Turonian flint (black dots) on the background of the other Magdalenian sites in eastern Central Europe (white dots), 1 - Stare Baraki 1; 2 - Podgrodzie 16; 3 - Ćmielów 95; 4 - Jankowice 49; 5 - Wilczyce 10; 6 - Zawichost-Trójca 30; 7 Wąwolnica (Laki 2); 8 - Klementowice 20; 9 - Wierzawice 31; 10 Łąka 3; 11 - Mosty 13; 12 - Hłomcza 1; 13 - Pekárna Cave; 14 Oelknitz; b Magdalenian sites near the area of the Turonian flint deposits (numbering as in a); $\mathbf{c}$ archaeological sites within the area of the eastern Turonian flint deposits, 1 - Annopol 7; 2 - Annopol 19; 3 - Gościeradów

recorded are located in the eastern part of the area settled by this community, along the San river and the middle Vistula

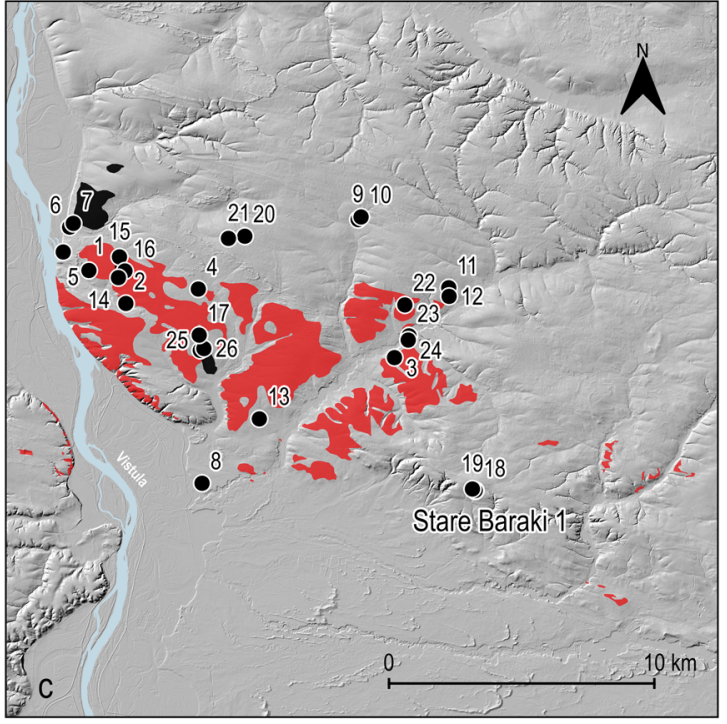

71; 4 - Huta 4; 5 - Jakubowice 2; 6 - Kopiec 4; 7 - Świeciechów Poduchowny 1; 8 - Kosin 16; 9 - Księżomierz 8; 10 - Księżomierz 10; 11 - Liśnik Duży Kolonia 6; 12 - Liśnik Duży Kolonia 7; 13 - Mniszek 18; 14 - Nowy Rachów 5; 15 - Nowy Rachów 26; 16 - Nowy Rachów 30; 17 - Opoka Kolonia 22;18 - Stare Baraki 1; 19 - Stare Baraki 2; 20 Sucha Wólka 7; 21 - Sucha Wólka 8; 22 - Wólka Gościeradowska 30; 23 - Wólka Gościeradowska 56; 24 - Wólka Gościeradowska 60; 25 Wymysłów 49; 26 - Wymysłów 50. Outcrops of Świeciechów flint are shown in black, outcrops of other Turonian flints in red

river (Fig. 1). The largest contribution of Turonian flints in the raw material structure has been recorded at sites located in the 
immediate proximity of outcrops of this material, on both banks of the Vistula (Online Resource 1). Regarding the contribution of Turonian flint in individual inventories, the current data suggest that: (i) most often, it is one of two dominant raw materials (next to the chocolate flint); (ii) it is a dominant raw material; or (iii) there are single artefacts made from this flint, particularly at sites located at a distance exceeding $100 \mathrm{~km}$ from the outcrop.

To date, the presence of Turonian flint has been confirmed at a total of 14 sites (Fig. 1 and Online Resource 1). Six of them were located within a radius of up to $25 \mathrm{~km}$ around the outcrop, the other four at a distance of up to $100 \mathrm{~km}$, and three at a distance exceeding $100 \mathrm{~km}$. The sites vary in size, function, settlement duration and chronology (Połtowicz-Bobak 2013; Bobak et al. 2017). Single specimens of Świeciechów flint have also been recorded at remote sites in the Pekárna Cave in Moravia, Czech Republic (ca. $500 \mathrm{~km}$ ) (Bednarz 1998; Valoch 2009) and in Oelknitz in eastern Thuringia, Germany (ca. 800 km) (Ginter 1974: pp. 10, 64). In the case of these two sites, and especially the very remote site at Oelknitz, it should be emphasised that the raw material identification was based on macroscopic characteristics alone. Accordingly, these interpretations should be regarded with caution.

The site in Hłomcza, in the Polish Carpathians, is the furthest site from the WTF and ETF outcrops in Poland (approx. $150 \mathrm{~km}$ ), which contains Turonian flint artefacts. Nearly the entire inventory is made of the local Bircza flint (Laptaś et al. 2002), while Turonian flint was recorded only in two single tools made of Świeciechów flint (burin and end-scraper $1.25 \%$ of the assemblage) (Eanczont et al. 2002). The research at the site in Mosty in the Świetokrzyskie Mountains, which is situated approx. $100 \mathrm{~km}$ to the west of Turonian flint outcrops (Cyrek 1986), yielded one blade of Świeciechów flint, which makes up $0.15 \%$ of the raw material structure.

Sites within a $100 \mathrm{~km}$ distance from the outcrops include Wierzawice and Łaka, located at the middle San river. Their inventories are characterised by a significant share of Turonian flints, next to the chocolate flint and erratic Cretaceous flint. Artefacts made of ETF include cores, debitage and tools (Bobak et al. 2010; Bobak et al. 2017; Bobak and Poltowicz-Bobak 2014).

Approx. $60 \mathrm{~km}$ to the north of the ETF outcrop there is another Magdalenian site in Klementowice (Wiśniewski et al. 2012a; Wiśniewski 2015). The ETF, the chocolate flint and the erratic Cretaceous flint prevail in the raw material structure. The inventory includes cores, debitage and tools. Not far from Klementowice, approx. $7 \mathrm{~km}$ to the south, there is a site in Wąwolnica (Laki 2), which has recently been excavated by T. Wiśniewski. Typo-technological features of artefacts and absolute dating indicate the Magdalenian technocomplex (unpublished data). Its scant inventory includes one end-scraper of the Świeciechów flint. The presence of artefacts made of the chocolate flint and the erratic Cretaceous flint has also been confirmed.

Until now, five Magdalenian sites were identified in close proximity of the Turonian flint outcrops: Podgrodzie 16, Ćmielów 95-Mały Gawroniec, Jankowice 49, Wilczyce 10, and Zawichost-Trójca 30 (Fig. 1b and Online Resource 1). All of them are located at the western side of the Vistula river, within WTF outcrops, however, both WTF and ETF (especially, the Świeciechów flint) are present in their lithic inventories. All of them are situated up to about $25 \mathrm{~km}$ away from the ETF outcrops.

The greatest number of flint lithics is known from the site in Wilczyce, where Turonian and chocolate flints are the most prevalent raw materials (Fiedorczuk et al. 2007; Królik 2014; Schild 2014). The majority of them have been most likely obtained from outcrops located in the vicinity of the site. However, the inventory also included a collection of artefacts made of Świeciechów flint, such as tools, blades and trimming blades. As artefacts are heavily patinated, the accurate identification of Turonian flint variety is difficult. Portable art from Wilczyce in a form of schematic female figurines is a unique discovery. The collection comprises 58 specimens made of Turonian flint (39 items), chocolate flint (15 items) and 4 items of unidentified raw material. The figurines were made of flint flakes and blades using the chipping technique (Fiedorczuk et al. 2007; Boroń et al. 2014; WiniarskaKabacińska 2014).

Another trace of settlement is the site in Ćmielów-Mały Gawroniec, where Turonian and chocolate flint are the two most prevalent raw materials. Remains of unidentified constructions were found there, together with a variable inventory of lithic artefacts and hematite portable art. Two dominating raw materials are the Turonian flint and the chocolate flint. Turonian flint varieties include both WTF and ETF (among others, the Świeciechów flint) (Przeździecki et al. 2011a, 2012). Research conducted at the site yielded cores, products of debitage and tools.

Approximately $3 \mathrm{~km}$ to the north of Ćmielów-Mały Gawroniec is a site in Podgrodzie (Przeździecki et al. 2011b; Pyżewicz 2015a). Similarly to other sites where Turonian flints were dominant, the Świeciechów flint is the most abundant at this site. The excavation yielded mainly products of debitage and some tools. Small collections of artefacts were also found at two other nearby sites, Zawichost-Trójca and Jankowice, where the Świeciechów flint was recorded (Migal 2008).

Turonian flints were used in the easternmost Magdalenian primarily for the production of tools (Królik 2014; Wiśniewski 2015; Przeździecki et al. 2011a), elements of hunting weapons (backed bladelets), and in the processing of animal-derived materials (e.g. burins, end-scrapers and becs). This has been confirmed by a use-wear analysis conducted at several sites, such as Wilczyce, Podgrodzie and 
Klementowice (Winiarska-Kabacińska 2014; Pyżewicz 2015a, 2015b). The analysis revealed that some objects made of Turonian flint were used at these sites for a number of different purposes (e.g. fire-lighting, antler/bone working and leather processing). Generally, Magdalenian inventories of Turonian flint lithics include diverse sets of tools connected with home management and hunting. Cores and products of debitage are also common. Until now, no preferential selection of particular raw materials for production of particular types of tools has been identified.

\section{Magdalenian settlement within the deposit area}

The presence of ETF, which outcrops on the east side of the Vistula river, in the inventories of Magdalenian sites located on the west side of the river, strongly points toward the frequent penetration of the ETF outcrop area by Magdalenian societies and possibly the presence of potential settlements there.

Workshops from the area of ETF, generally dated to the Late Palaeolithic or Mesolithic, were recorded as early as the 1920s1930s (Libera 1998: pp. 86-87, 92-93). Further researches, aiming at the determination of the scope of Turonian raw materials on the east bank of the Vistula river, also yielded new discoveries connected with this period (Libera 2002). However, none of these sites can be unambiguously linked with Magdalenian. Analysis of the currently known distribution of Magdalenian sites within the Turonian outcrops reveals no certain settlement at the east side of the Vistula river, within the ETF outcrops (Fig. 1c). We hypothesise that this is an effect of the insufficient state of archaeological recognition in this zone.

The article aims to determine the nature of the exploitation of the ETF outcrop area by the Magdalenian communities, and the ways they managed the Turonian raw material.

\section{Methods and materials}

\section{Searching for Magdalenian sites}

The study was conducted as part of the research project "Late Palaeolithic settlement in the western part of the Lublin Upland" led by T. Wiśniewski. One of its aims was to explore traces of Magdalenian activity in the western part of the Lublin Upland.

The first phase was verification and analysis of archive data, which involved querying AZP (Archaeological Map of Poland) data and unpublished collections of flint artefacts from the investigated area, deposited at the Institute of Archaeology of the Maria Curie-Skłodowska University in Lublin and the State Archaeological Museum in Warsaw.
Based on archive material, the sites with lithic artefacts with typo-technological features characteristic of Late Palaeolithic were picked out (Przeździecki et al. 2011b; Pyżewicz et al. 2014). We also considered their preservation state (presence of patina) and raw materials structure, which are typical of easternmost Magdalenian (Połtowicz-Bobak 2013; Wiśniewski 2015) and help to preliminary indicate the possible Magdalenian sites. In total, 26 sites were selected for surface surveys.

In summer 2018, two-week surface surveys were carried out within the ETF outcrop and its immediate vicinity. The research area encompassed approx. $200 \mathrm{~km}^{2}$. All artefacts discovered during the surveys were located with Garmin GPSMap 64st, which enabled mapping of artefact distribution. Positive results of these investigations made it possible to plan and carry out reconnaissance excavations. This stage also involved collecting of new artefacts and samples for specialist analyses.

\section{Excavations}

Archaeological excavation at a selected site (i.e., Stare Baraki site, see "The Turonian flint economy at Stare Baraki," "Magdalenian sites within the Turonian flint deposit area") was conducted in summer 2018. The excavation area was divided into eight test trenches, investigating in total an area of $14.5 \mathrm{~m}^{2}$. The sedimentary sequences of trenches were divided into stratigraphic units, based on lithological differences. Those units which clearly correlated between the trenches were given the same numeration. Basic lithological parameters of the sedimentary units were identified in the field. Those included colour (checked for freshly excavated sediment with the use of Munsell Soil Colour Chart) and $\mathrm{CaCO}_{3}$ content (checked as reaction with $10 \% \mathrm{HCl}$ ). Sediment texture (grains size, consistency, cohesion) was noted, and the presence of any sedimentary or post-sedimentary macrostructures was noted and photographed.

All artefacts were localised in 3D mode with use of the total station, with $\pm 1 \mathrm{~cm}$ accuracy. Surficial finds were also localised at the area of $2000 \mathrm{~m}^{2}$ around the trenches. Removed sediment was dry-sieved through $3 \mathrm{~mm}$ mesh, and selected samples were water-sieved through $2 \mathrm{~mm}$ mesh. The spatial distribution of artefacts was analysed and visualised with the use of QGIS 3.8 Zanzibar software.

\section{Micromorphology}

Micromorphological analysis of two blocks of undisturbed sediment was used to elucidate the processes responsible for site formation. Samples were collected from trench W8. The blocks were impregnated with resin, and two thin sections made from each block, following procedures described elsewhere (e.g. Krajcarz et al. 2016; Morley et al. 2017). 
Diagnostic features observed using a polarising microscope were recorded for each stratigraphic unit using standard protocols (Stoops 2003; Stoops et al. 2010) with special attention given to pedofeatures known from loess deposits of southern Poland (Mroczek 2018). Terminology follows Stoops (2008).

\section{Dating}

Four samples for OLS dating were collected in order to determine the absolute age of sediments, including one sample from the upper part of artefact-bearing sediments, one sample from its lower part, and two others from the deeper part of the section artefact. Sampling was conducted according to the well-established protocol (Nelson et al. 2015). OSL dating followed the methodology described by Fedorowicz et al. (2018). It was performed at OSL Lab in Maria CurieSklodowska University in Lublin (Poland), using the RISO TL/OSL DA-20 reader equipped with U340 filter. The sample was stimulated by blue LEDs $(470 \mathrm{~nm})$ delivering $\sim 60$ $\mathrm{mW} / \mathrm{cm}^{2}$. During measurement, the sample was irradiated by ${ }^{90} \mathrm{Sr} /{ }^{90} \mathrm{Y}$ beta source. The equivalent dose (De) was determined using the SAR procedure (Murray and Wintle 2000) and statistical model averaging the single-aliquot measurement. The annual dose was determined by measuring ${ }^{226} \mathrm{Ra}$, ${ }^{228} \mathrm{Th}$, and ${ }^{40} \mathrm{~K}$ radionuclide concentrations. Each sample was analysed 40 to 100 times with each measurement lasted 2000 $\mathrm{s}$. The radionuclide concentrations were converted into alpha $(\mathrm{d} \alpha)$, beta $(\mathrm{d} \beta)$ and gamma $(\mathrm{d} \gamma)$ doses, using conversion factor procedure (Adamiec and Aitken 1998). The average values were measured for a grain size range of 45-63 $\mu \mathrm{m}$.

In addition, a charcoal fragment found in the sediment was dated with radiocarbon method. AMS dating of cellulose was conducted in the Poznan Radiocarbon Laboratory (Poland). Cellulose extraction and purification followed a widely accepted methodology (Goslar et al. 2004; Brock et al. 2010). The obtained radiocarbon age was calibrated versus the INTCAL'13 radiocarbon atmospheric calibration curve (Reimer et al. 2013), using the OxCal software, ver. 4.3.2 (Bronk Ramsey 2009, 2017; Bronk Ramsey et al. 2013).

To identify chronological ranges of the stratigraphic units, all obtained dates were inserted in OxCal sequence model. The model's "phases" were the dates grouped by stratigraphic units (separately, Units 3-2b, Unit 2a, and Unit A), and model's "boundaries" were the boundaries between these units. Bayesian statistical modelling followed Bronk Ramsey (2008). The details of the model are provided in Online Resource 3.

\section{Analysis of archaeological material}

This paper focuses on the analysis of chipped flint artefacts from excavations conducted in 2018 and materials from earlier surface surveys (Wiśniewski 2020). The whole inventory (i.e., artefacts from all tranches and stratigraphic units, and surface finds) was treated as one assemblage. No other traces of prehistoric settlement were found at the site. Preliminary description of typo-technological features of artefacts indicated that they were of the same origin, which seems to be confirmed by refittings of flint artefacts from individual trenches and artefacts from the surface.

Analysis of chipped flint artefacts was based on dynamic technological classification (Schild 1980; Sørensen 2006, 2008), and included a total of 916 specimens. Basic metric values were also given for individual artefact categories. The research involved analysis of individual attributes of blade blanks. Terminology and description pattern were based on selected literature (Inizan et al. 1999; Pelegrin 2000; Valentin and Pigeot 2000; Valentin 2008; Demars and Laurent 1989). The form of description for individual features of blades was based mostly on the system used by A. Maier (2015: pp. 2833). Results of experimental research carried out on the basis of materials from Magdalenian sites from the neighbouring Kielce Upland were also applied (Pyżewicz et al. 2014).

Technological analysis of blades was conducted for a selected sample, which included fully and partially-preserved specimens. Most relevant were proximal parts of blades with preserved butts.

\section{Identification of raw material}

Classification of Turonian silicites has been provided in the literature (Balcer 1975; Michniak 1989; Domański and Webb 2000; Libera and Zakościelna 2002; Domański et al. 2009; Król and Migaszewski 2009; Přichystal 2013). Some varieties are named after the town or village situated near their outcrops. The classification was based mostly on differences in colour, transparency, lustre, presence of spotting, size of nodules, and the texture and thickness of the cortex. Searching for microscopic and geochemical differences did not find any regular characteristics (Szeliga and Huber 2016). The varieties occurring to the west of Vistula river (hereafter, the Western Turonian Flints, or WTF) include Ożarów flint, Janików flint, and Zawada flint (Krukowski 1920: p. 195; Krzak 1965: p. 222, 1970: pp. 292295; Balcer 1975: pp. 45-53; Budziszewski 1986; Libera and Zakościelna 2002: pp. 96-100; Přichystal 2013). To the east of Vistula river, four varieties were recognised until now (hereafter, Eastern Turonian Flints, or ETF): (1) white-spotted grey flint (Świeciechów flint, SW); (2) grey patchy flint (Gościeradów flint, GC); (3) grey flint without spotting; and (4) black flint (Libera and Zakościelna 2002: p. 96, 2019: p. 24). The most characteristic and recognisable variety of the ETF in archaeological material is the Świeciechów flint (Online Resource 5: S0a). It was commonly used by Palaeolithic, Neolithic and Bronze Age societies due to its perfect knapping properties and large nodule size. Its nodules available nowadays at the ground surface exceed $50 \mathrm{~cm}$ and $15 \mathrm{~kg}$, and probably the largest ones are not preserved, as they were utilised in prehistory. Properties of the 
grey flint without spotting are similar to those of Świeciechów flint. The Gościeradów flint also has high utility values; however, its nodules are smaller, $15-20 \mathrm{~cm}$ on average (Online Resource 5: S0b). The black flint has limited usefulness for lithic production. Its nodules are usually irregularly fractured and tend to crumble into ragged pieces. ETF outcrops were first found by S. Krukowski and J. Samsonowicz (Krukowski 1920; Samsonowicz 1924), and their spatial distribution was studied in details by Z. Krzak (1965, 1970), B. Balcer (1975), Libera and Zakościelna (2002).

For macroscopic identification of raw material, we used the guidelines provided in the literature (Balcer 1975; Michniak 1989; Domański and Webb 2000; Libera and Zakościelna 2002; Domański et al. 2009; Król and Migaszewski 2009; Prrichystal 2013) and collections from the lithic depository of the Institute of Archaeology of MCSU in Lublin. Raw materials were identified by comparing the following: (i) dimension, thickness and colour of cortex; (ii) colour, lustre and spotting of siliceous substance; and (iii) fracture and flintknapping properties. During field surveys, the comparative collection was expanded by including newly collected specimens. The ETF has rather easily recognisable macroscopic characteristics; therefore, considering the regional scope of this study and the generally well-known outcrops situation in south-eastern Poland, the identification based on macroscopic criteria appears permissible. Beside the ETF and its varieties, we also considered: Turonian flint from the west bank of the Vistula River; erratic Cretaceous flint (ECF); Cretaceous Volhynian flint; and many well-known varieties of Jurassic cherts (such as chocolate flint, striped flint, and variable cherts from Polish Jura).

The current state of knowledge does not allow for establishing unambiguous criteria to identify the particular varieties of Turonian flint in archaeological materials. Moreover, among the Magdalenian inventories from the area in question, the vast majority of flint artefacts are covered with a patina of varying degrees of intensity. In many cases, this makes the precise identification impossible, especially in the case of small specimens, such as chips. Therefore, for some specimens, it was only possible to identify the affinity to undivided ETFs, without further attribution to a variety.

To describe the provenience of lithic raw materials by distance from a source location to the sites, we adopted the following ranges: local $(<20 \mathrm{~km})$, regional $(20-100 \mathrm{~km})$, and extra-regional $(>100 \mathrm{~km})$.

\section{Results}

\section{Magdalenian sites within the Turonian flint deposit area}

Archaeological surveys conducted in the 1920s-1930s provided the first data on Late Palaeolithic settlement in the research area. These investigations were carried out by $\mathrm{S}$. Krukowski and R. Jakimowicz and revealed workshops situated in the outcrop area of grey flint in Jakubowice, Rachów and Sucha Wólka (Libera 2002: p. 29). After the Second World War, the database was expanded by Z. Krzak (1965), B. Balcer (1971, 1975) and J. Gurba (1970).

For a long time it was believed that the ETF had only minor significance for Palaeolithic communities (see Ginter 1974: p. 10; Sulgostowska 1989: p. 34). This changed after the research program focused on pre-Neolithic settlement in central-eastern Poland, undertaken by J. Libera in 1980s. Then, numerous collections of ETF artefacts, including those from unpublished pre-WW2 research, have been revealed. They were deposited mainly at the State Archaeological Museum in Warsaw and other regional museums (Libera 1995, 1998). Unfortunately, many materials from the former research lack detail localisation.

Surveys conducted in the 1980 s yielded particularly interesting results, enabling identification of the range of ETF outcrops (Libera 2002; Libera and Zakościelna 2002, 2019). Artefact analysis indicated that Świeciechów flint was exploited mainly during the Late Palaeolithic, Mesolithic, Neolithic and Eneolithic, while the Gościeradów variety was used from the Early Bronze Age until the beginning of the Hallstatt Period. Remains of Late Palaeolithic were recorded at 22 sites, many of which are most probably connected with the Swiderian technocomplex (Libera and Zakościelna 2019: pp. 12-14, Fig. 1). They were distinguished based on double platform cores with common flaking surface and blade blanks derived from them (Libera 2002: Figs. 1, 2, 3, 4). The investigations also revealed a Swiderian flint workshop in Kopiec, situated at a distance of approx. 500 metres to the south of the Świeciechów flint outcrop, which was later subject to excavations (Florek and Libera 1994; Libera 2002: p. 35; Libera and Zakościelna 2019: pp. 21-23).

Among sites known from literature and archival materials, 26 sites revealed features suggesting possible Magdalenian affiliation (Fig. 1c). Our 2018 field survey yielded 14 negative results (Annopol 8, Gościeradów 71, Huta 4, Kosin 16, Księżomierz 6, Liśnik Duży Kolonia 7, Nowy Rachów 5, Opoka Kolonia 22, Sucha Wólka 8, Wólka Gościeradowska 30, 56, 60 and Wymysłów 49, 50). At these sites, surveys did not provide any artefacts, or the area was not available for research. Verification at farther 12 sites brought positive results, which meant that surveys provided some artefacts with Palaeolithic typo-technological features (Jakubowice 2, Kopiec 4, 5, Księżomierz 8, Liśnik Duży Kolonia 6, Nowy Rachów 26, 30, Stare Baraki (Salomin) 1, 2, Sucha Wólka 7).

The only site within the region which can be undoubtedly classified as Magdalenian on the basis of techno-typological characteristics of lithic material collected during survey studies is Stare Baraki 1. This site was first discovered during archaeological survey campaign conducted by researchers 


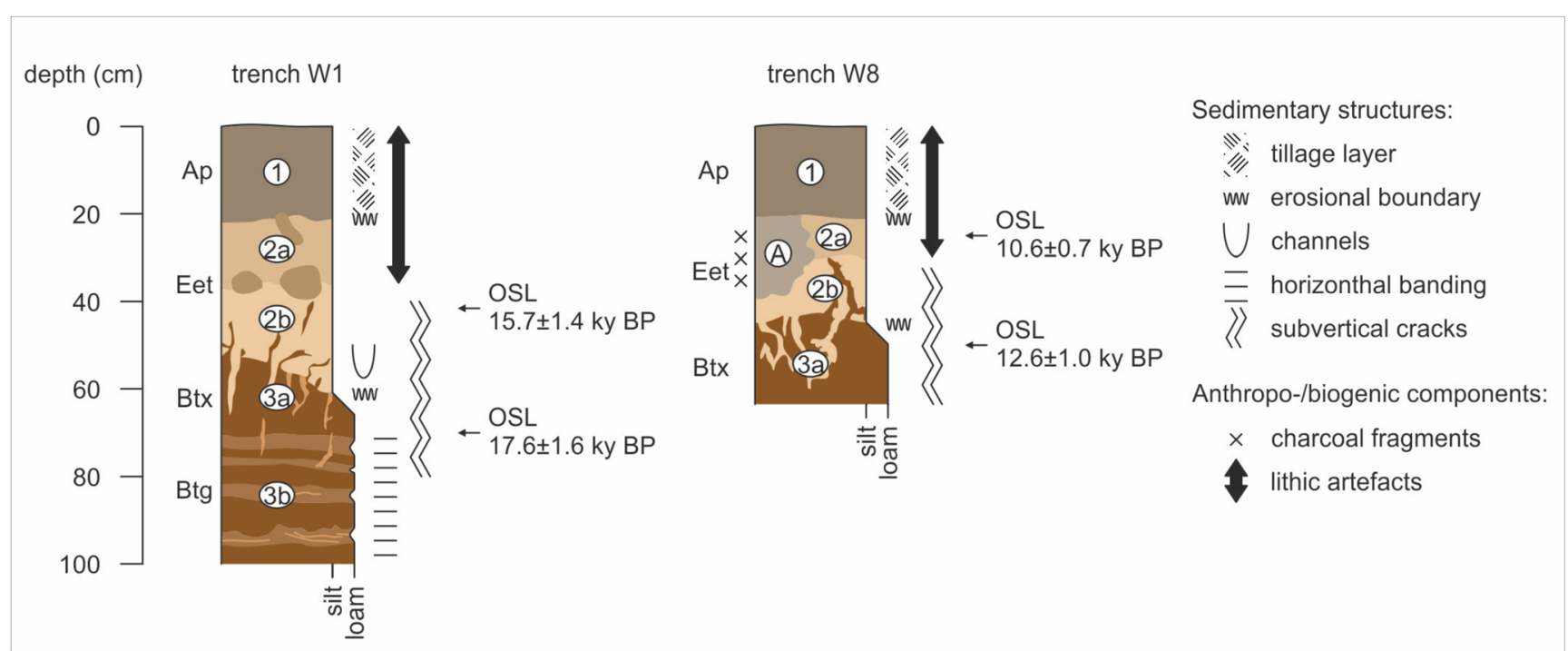

Fig. 2 Stratigraphy of the Stare Baraki 1, excavation trenches W1 and W8

from MCSU in Lublin in 1985. Due to sparse finds, it was generally dated to the Late Palaeolithic (Libera 2002: p. 39).
Surveys managed in 2018 yielded numerous flint artefacts (cores, debitage, tools). Their typological and technological

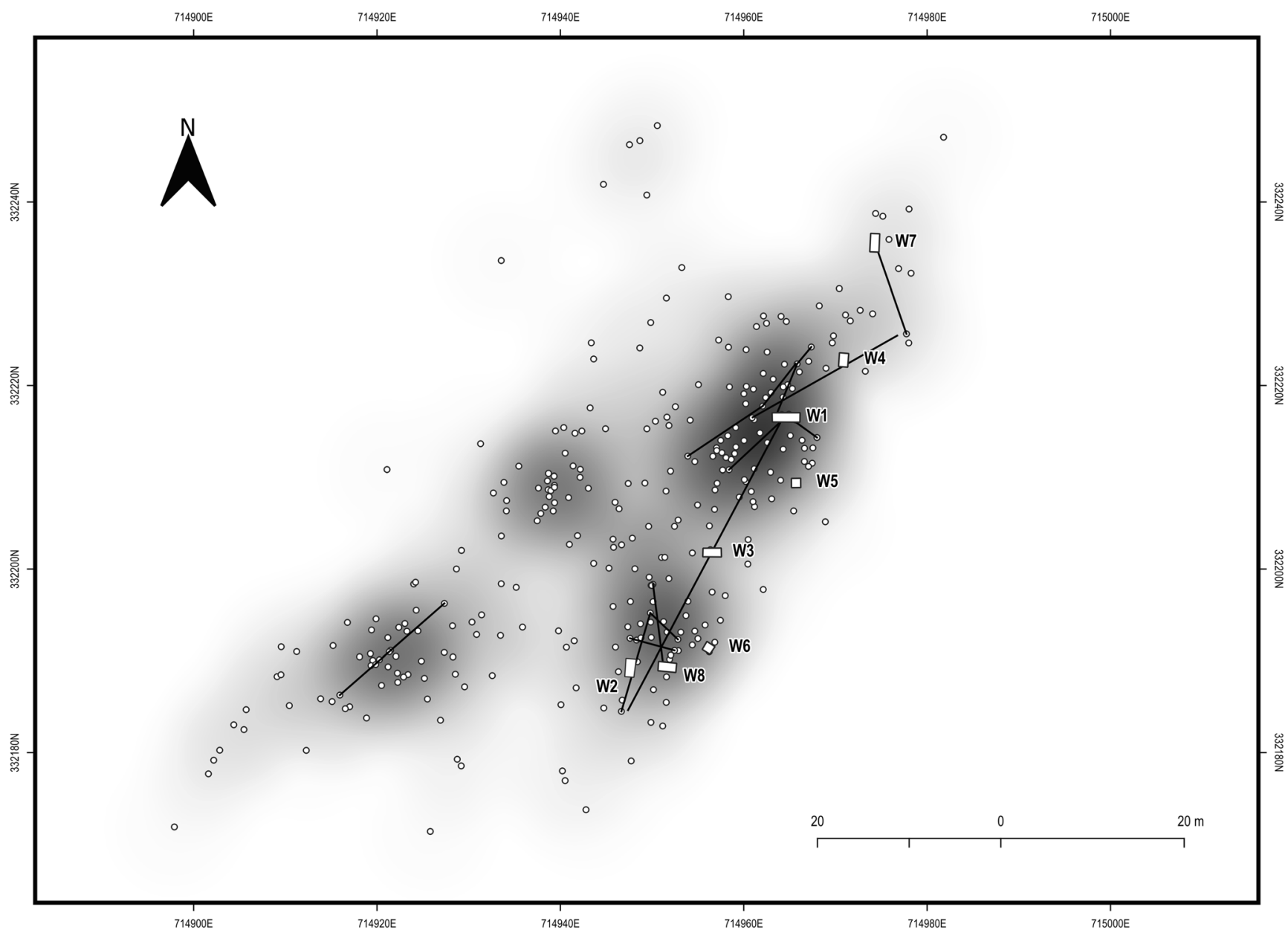

Fig. 3 Distribution and density of artefacts discovered at Stare Baraki, site 1, during the surface survey W1-W8 - numbering of trenches during excavations in 2018. Black lines: refits of artefacts 


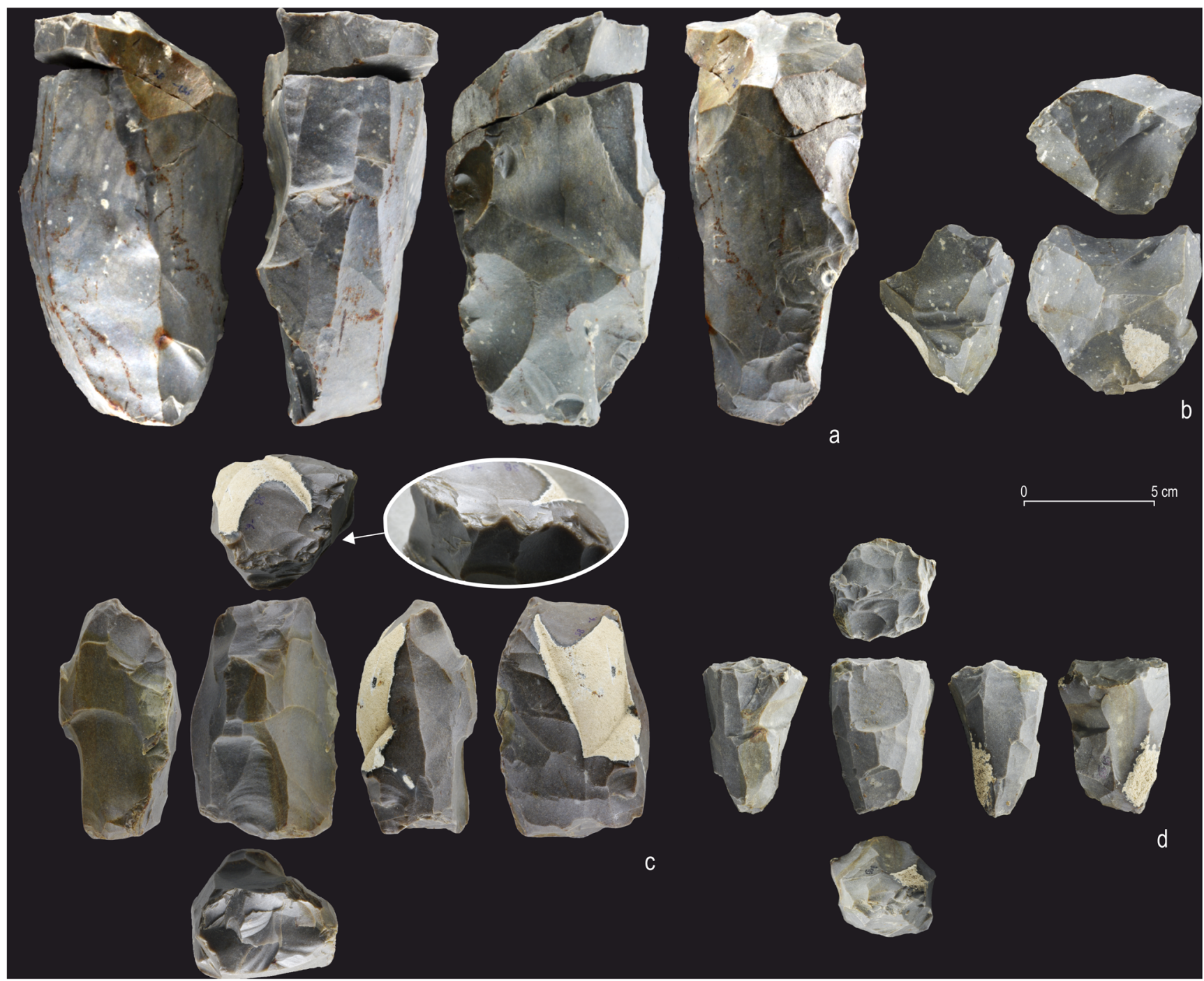

Fig. 4 Cores from Stare Baraki, site 1, made from Turonian flint: a, b Świeciechów flint (SW); c, d Gościeradów flint (GC)

features indicated a close resemblance to inventories of the Magdalenian technocomplex (Wiśniewski 2020). Therefore, this site was selected for excavation research.

\section{Stare Baraki-geomorphological and geological situation}

The site Stare Baraki 1 is situated at the top of a hill, at an altitude of $267.60 \mathrm{~m}$ a.s.l. (geographic coordinates: $\mathrm{N} 50^{\circ} 49^{\prime}$ $0.81^{\prime \prime}$, E $\left.22^{\circ} 3^{\prime} 9.77^{\prime \prime}\right)$. It is located at the boundary of two large geographic provinces: the Meta-Carpathian foreland (socalled Polish Uplands, in particular, the Lublin Upland) to the north; and Carpathian foredeep to the south (so-called Sandomierz Basin) (Kondracki 2009). The northern region includes elevated uplands (usually over $200 \mathrm{~m}$ a.s.l.) with variable relief. The basement of this area is Mesozoic rocks, mostly Cretaceous, with sparse Jurassic outcropping in the local anticlines' hinges (Pożaryski 1948; Świdrowska 2007).
Although deformed by later fault tectonics, the Mesozoic strata retained general monoclinal structure, with dips toward NNE (Geological Map of Poland). As a consequence, the following stratigraphic stages (i.e., Turonian, Coniacian, Santonian, and Campanian) outcrop more-or-less along WNW-ESE lines. Locally, fault tectonic structures (i.e., Annopol Anticline, Gościeradów Anticline, and Salomin Anticline) deform this regional pattern. Mesozoic is covered by Neogene and Quaternary deposits, whose total thickness locally exceeds $100 \mathrm{~m}$ (Bielecka 1968). The most widespread facies here is Upper Pleistocene loess and loess-like deposits. Neogene and Mesozoic outcrops are situated at slopes within the river valleys and gorges and have a limited size. Cherts occur in all Cretaceous stages. Among them, Turonian flints are of particular interest. Coniacian, Santonian, and Campanian limestones also contain silicites (Bielecka 1968; Włodek and Gaździcka 2009); these cherts, however, are of poor quality and have not been systematically studied. 
The boundary between southern and northern regions runs along with the tectonic dislocation. The southern region is a vast peneplain. Middle and Upper Pleistocene fluvial and glacifluvial sands are the dominant facies here, accompanied by aeolian sands and dispersed outcrops of glacial tills (Bielecka 1968; Libera et al. 1991/1992: p. 23). These sediments contain erratic Cretaceous flints of good knapping properties, but the pieces are usually small and cracked.

The Stare Baraki site is situated in the northern region, at the crest elongated along WNW-ESE direction, which constitutes the southern edge of the Lublin Upland. The crest is built of Upper Pleistocene loess. Its southern and northern slopes are covered by loess-like deposits, which according to Pożaryski (1953) and Bielecka (1968) represent the terminal phase of the Last Glacial, the Younger Dryas Stadial. Toward the north the landscape is dominated by gentle hills of a loess plateau. At the south the crest is limited by a long slope, which runs down to Karasiówka stream valley, a part of the southern region, i.e., the Sandomierz Basin. The slope is cut by several gorges and ravines (Libera et al. 1991/1992; Kondracki 2009: p. 284), the largest of them being the upper segment of the Karasiówka valley. Numerous small outcrops of Turonian rocks with cherts are situated within this gorge. Maximum denivelation between the site and the Karasiówka valley reaches around $100 \mathrm{~m}$. At a distance of about $7 \mathrm{~km}$ toward the NW, there is another valley of the Tuczyn river. The largest river, the Vistula, is around $12 \mathrm{~km}$ away to the west.

\section{Stratigraphy and chronology}

Six stratigraphic units were distinguished at the excavation zones (Table 1 and Fig. 2). The uppermost Unit 1 is a plough layer (Ap soil horizon), currently cultivated. It is a loose humiferous grey silt, with sharp, erosional, and undulating lower boundary, a typical structure produced by tillage. In trench W8, directly below the Unit 1, there was another stratigraphic unit of limited lateral distribution, called Unit A. It had a form of a shallow pit (around $20 \mathrm{~cm}$ deep), more-or-less circular in plan, with around $50 \mathrm{~cm}$ diameter. Infill of this pit was massive, loose silt with numerous charcoal fragments. This unit represents either an enigmatic post-Palaeolithic anthropogenic feature or natural windthrow.

Unit 2 represents the eluvial (E) soil horizon. It has been subdivided into two Subunits $-2 \mathrm{a}$ and $2 \mathrm{~b}$, on the base on differences in texture and colour. The Subunit 2a is the primary source of Palaeolithic artefacts, which can be found also within Unit 1 and at the surface of the terrain. It is massive pale silt with lenticular microstructure (Online Resource 2), which testifies the intense frost action (see: Van Vliet-Lanoë et al. 2004a, 2004b; Stoops et al. 2010) and indicates that the sediment was exposed to periglacial conditions. Downward it passes into Subunit $2 \mathrm{~b}$ without any clear boundary. The Subunit $2 b$ has a macro-prismatic texture, with very pale,

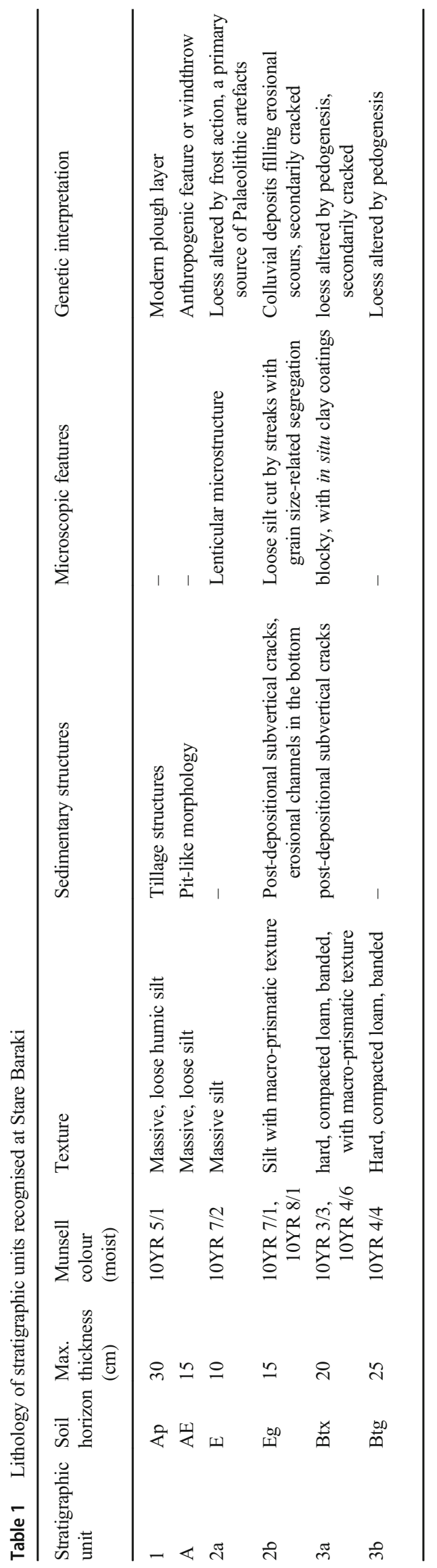


bleached polygons separated by subvertical or irregular brownish streaks. The micromorphological analysis revealed grain-size-related segregation within these structures - central parts are porous and dominated by silt grains, while finer material (fine silt and clay) is compacted at both sides of a streak (Online Resource 2). This indicates the centre-to-side translocation of the finest material within the streaks and points out toward hydraulic pressure which was active in the past, likely as an effect of frost action (Van Vliet-Lanoë et al. 2004a, 2004b). The lower boundary of the Subunit $2 b$ is sharp and erosional. In some trenches, the erosional channels are preserved, cut into the lower unit (i.e., Subunit 3a). These structures are around $30-50 \mathrm{~cm}$ wide and around $10-15 \mathrm{~cm}$ deep, and suggest erosion and partial re-deposition of the Subunit's 3a material. Presence of clay papules (irregularly distributed cracked fragments of clay coatings) within the Subunit $2 b$, revealed by micromorphology (Online Resource 2 ), additionally proves the erosion followed by colluvial redeposition during the formation of this unit (compare: Mroczek 2018; Poręba et al. 2019).

Unit 3 is a hard, compacted brown loam with distinct macroprismatic texture. The loamy brown peds, usually around 10-15 $\mathrm{cm}$ in diameter, have clear banded macro- and microfabric. They are separated by around 1-to-3-cm-wide subvertical fissures filled with silty material, similar to that of the upper units. In plan, the fissures form a net-like polygonal pattern. This morphology resembles the fragipan horizon (Smalley et al. 2016), observed in some forest soils of southern Poland (Szymański et al. 2011), or so-called "ABC soils" known from western Europe (Dondeyne and Deckers 2019). Animal burrows, some quite large (up to $40 \mathrm{~cm}$ in diameter), are common within this unit and locally disturb its original texture and structures. Polygonal texture disappears at depth of around $40-50 \mathrm{~cm}$ below the top of Unit 3, and this characteristic was used to subdivide the unit into two indistinct Subunits: $3 \mathrm{a}$ and $3 \mathrm{~b}$. The entire Unit 3 is settled within the illuviation horizon (Bt). Noteworthy, presence of erosional channels at the bottom of Subunit $2 b$, which clearly cut the illuvium, suggests that the illuviation and soil development happened before the deposition of Unit 2, and before the Magdalenian settlement.

Achieved OSL dates testify the Upper Pleistocene (and possibly also Lower Holocene) age of the sediments at Stare Baraki (Table 2). Entire sequence underlying the Palaeolithic level (i.e. Subunits: $3 b, 3 a$ and $2 b$ ) can be dated to around
17.6-12.6 ky BP. Around 5 ky difference between two dates from the Subunit 3 a may be an effect of contamination of the LUB-6535 sample by a younger material (from Units 1 and/or 2 ), transported downward along the cracks or by bioturbation. The Subunit 2a, containing the Palaeolithic level, revealed the date of $10.6 \pm 0.7 \mathrm{ky}$ BP. However, this date was achieved on a sample taken quite shallow below the modern ground surface $(25 \mathrm{~cm})$, and directly below the tillage layer, therefore this age should be considered with caution. On the other hand, because the sample was taken from the upper part of the Palaeolithic-bearing unit, it may post-date the settlement. Following this assumption, the age of settlement ranges between the dates for Subunit 2a and the lower units. The statistical boundary between them was modelled in OxCal to 13.3$10.8 \mathrm{ky} \mathrm{BP}$ (with $68.2 \%$ probability) or $14.5-10.0 \mathrm{ky} \mathrm{BP}$ (95.4\%) (Online Resource 3).

Radiocarbon age of a charcoal fragment allows dating the Unit A to around $3 \mathrm{ky}$ BP (Bronze Age/Iron Age) (Table 3). Taxonomic identification of the charcoal (thanks to the curtesy of Dr. Magdalena Moskal-del Hoyo) indicated oak (Quercus), which was a typical component of Holocene flora of Poland (Ralska-Jasiewiczowa et al. 2004) and fits well to the dating result. Both the stratigraphic position of the Unit A and its radiocarbon dating clearly post-date the Magdalenian settlement.

\section{Distribution of artefacts}

Based on the distribution of artefacts on the surface, the total area of the site is estimated at approx. 2,000 square metres $(0.2$ hectare). The largest number of finds was recorded in trenches marked W1 and W8. During excavations, the artefacts were recorded within three stratigraphic units: Unit 1 (Ap soil horizon), Unit A, and Subunit 2a (E soil horizon). Excluding chips $(<15 \mathrm{~mm})$, only $4.89 \%$ of artefacts come from the Subunit 2a (Table 4). The vast majority of artefacts were recorded in Unit 1. In total, artefacts from this unit and those found at the surface make up over $90 \%$ of the whole inventory (Fig. 3 and Table 4).

At present, the site is a subject to intense agricultural activity. The strip layout of fields and tillage along the slope contribute to soil erosion, which results in degradation of the archaeological site. Many lithics bear traces of damage caused by agricultural machinery, which also causes systematic
Table 2 Stare Baraki, site 1. Optically stimulated luminescence ages (OSL) of 4 samples

\begin{tabular}{lllllll}
\hline Trench & Stratigraphic unit & $\begin{array}{l}\text { Relation to } \\
\text { Palaeolithic level }\end{array}$ & Lab number & OSL date (ky) & Depth m) & $\begin{array}{l}\text { Altitude } \\
\text { m a.s.1. }\end{array}$ \\
\hline W8 & $2 \mathrm{a}$ & Above & LUB-6534 & $10.6 \pm 0.7$ & 0.25 & 266.40 \\
W8 & $3 \mathrm{a}$ & Below & LUB-6535 & $12.6 \pm 1.0$ & 0.48 & 266.17 \\
W1 & 2b & Below & LUB-6601 & $15.7 \pm 1.4$ & 0.41 & 267.07 \\
W1 & 3a & Below & LUB-6602 & $17.6 \pm 1.6$ & 0.70 & 266.79 \\
\hline
\end{tabular}


Table 3 Stare Baraki, site 1. Radiocarbon age of charcoal from Unit A

\begin{tabular}{llllll}
\hline Trench & $\begin{array}{l}\text { Stratigraphic } \\
\text { unit }\end{array}$ & Lab number & 14C age (BP) & $\begin{array}{l}\text { Calibrated age (cal. BP, } \\
68.2 \% \text { probability })\end{array}$ & $\begin{array}{l}\text { Calibrated age (cal. BP, } \\
95.4 \% \text { probability) }\end{array}$ \\
\hline W8 & A & Poz-110804 & $2,880 \pm 35$ & $3060-2961$ & $3141-3125(2.0 \%)$ \\
& & & & $3110-3093(2.2 \%)$ \\
& & & $3080-2922(88.8 \%)$ \\
& & & & $2907-2888(2.4 \%)$ \\
\hline
\end{tabular}

relocation of archaeological material. The relocation was particularly intense in the south-west part of the site, where a slope is visibly inclined. Refitting between some lithics discovered in the plough level (Ap soil horizon) attests to significant relocation. The longest distance between two refitted elements was approx. $30 \mathrm{~m}$ (Fig. 3).

\section{Archaeological material}

\section{Structure of the inventory}

The inventory comprises of 922 artefacts in total (Table 5). The vast majority of them are chipped artefacts (916 specimens), followed by a small collection of stone slabs (6 specimens). The chipped artefacts were divided into six groups (Online Resource 4):

- group I - Early Core preparation $(N=20,4.05 \%)$;

- group II - Core Preparation and Flake Core Exploitation $(N=227,45.95 \%)$;

- group III - Early Blade Core Preparation and Exploitation $(N=75,15.18 \%)$;

- group IV - Advanced Blade Core Preparation and Exploitation $(N=130,26.32 \%)$;

- group V - Undetermined $(N=428)$;

- group VI - Tools $(N=42,8.50 \%)$

In each group, individual artefact categories were subdivided with regard to raw materials. The basic measurements of the chipped artefacts are presented in Online Resource 7.

Nearly all stages of flint processing have been identified at the site. The two most prevalent stages are group II (45.95\%) and group III (26.32\%). The two less common are group VI
(8.50\%) and group I (4.05\%). Group V Undetermined included artefacts which cannot be assigned to either of the groups. It has also been excluded from statistics, as it included uncharacteristic forms (undetermined flake fragments, chips and debris). This group comprises the most numerous collection, which results from the high efficiency of collecting very small pieces in the field, an effect of employed methodology (the sieving).

Most cores in the analysed inventory were produced from Turonian flint. Only two specimens were made of erratic Cretaceous flint. Cores are represented by specimens in various stages of core processing. Most of them are moderately exhausted and highly exhausted (Fig. 4 and Online Resource 5) (group IV). The early stage of exploration is represented by one specimen (group III). Flake core exploitation is represented by two specimens in a very highly exhausted stage of use (group II). The most numerous specimens are blade forms (9 of 11 specimens). Two specimens are flake forms. Singleplatform cores (6 specimens) predominate. Two doubleplatform specimens were also distinguished as well as one single-platform with changed orientation for bladelets.

The vast majority of flakes are specimens with unidirectional and multi-directional negative scars on dorsal faces (group II). A small collection is flaked with cortical or aeolian (natural) surfaces (group I). In the flake group, several core rejuvenation products were also distinguished. These are forms chipped off while shaping or modifying the core platform (tablets-group III and rejuvenation flakes-group IV).

The criterion for distinguishing blades and bladelets was the width, which for bladelets is $\leq 10 \mathrm{~mm}$. Based on this, only 19 specimens were identified as bladelets while 147 as blades. The vast majority of blades and bladelets were produced from ETF (groups III and IV). Many specimens have cortex or aeolian surfaces on their dorsal faces. Blades and bladelets also comprise core rejuvenation products, with specimens of
Table 4 Artefacts within stratigraphic units and soil horizons at Stare Baraki, site 1

\begin{tabular}{llllll}
\hline Stratigraphic unit (soil horizons) & Surface survey & Excavation & $\begin{array}{l}\text { Excavation } \\
\text { (sieving method) }\end{array}$ & $\mathrm{N}$ & $\%$ \\
\hline $1(\mathrm{Ap})$ & 363 & 143 & 336 & 842 & 91.32 \\
$2 \mathrm{a}(\mathrm{E})$ & - & 22 & 54 & 80 & 8.24 \\
A (AE) & - & 4 & - & - & 0.24 \\
Total & 363 & 169 & 390 & 922 & 100.00 \\
\hline
\end{tabular}


Table 5 Categories of artefacts within investigated trenches at Stare Baraki 1

\begin{tabular}{|c|c|c|c|c|c|c|c|c|c|c|c|c|}
\hline \multirow[t]{2}{*}{ Category } & \multirow[t]{2}{*}{ Surface survey } & \multicolumn{8}{|c|}{ Excavations (trenches) } & \multirow[t]{2}{*}{ Total } & \multirow[t]{2}{*}{$\%$ - without 9.} & \multirow[t]{2}{*}{$\%$ - without $5-7$ and 9.} \\
\hline & & $\mathrm{W} 1$ & W2 & W3 & W4 & W5 & W6 & W7 & W8 & & & \\
\hline 1. Cores & 10 & & & & & & & & 1 & 11 & 1,20 & 2,23 \\
\hline 2. Blades & 101 & 30 & 2 & 3 & 2 & & 1 & & 8 & 147 & 16,05 & 29,76 \\
\hline 3. Bladelets & & 7 & 3 & 1 & & 1 & & & 7 & 19 & 2,07 & 3,85 \\
\hline 4. Flakes & 122 & 90 & 11 & 14 & 7 & 4 & 2 & 2 & 23 & 275 & 30,02 & 55,67 \\
\hline 5. Chips & 28 & 171 & 28 & 12 & 16 & 8 & 3 & 2 & 68 & 336 & 36,68 & \\
\hline 6. Debris & 11 & & & & & & & & 1 & 12 & 1,31 & \\
\hline 7. Unidentified flakes & 74 & & & & & & & & & 74 & 8,08 & \\
\hline 8. Retouched and other tools & 26 & 4 & 3 & 2 & & 1 & & & 6 & 42 & 4,59 & 8,50 \\
\hline Total without 9 . & 298 & 302 & 47 & 32 & 25 & 14 & 6 & 4 & 114 & 916 & 100,00 & \\
\hline Total without 5-7 and 9. & 259 & 131 & 19 & 20 & 9 & 6 & 3 & 2 & 45 & 494 & & 100,00 \\
\hline 9. Stone slabs and other stone fragments & 3 & 3 & & & & & & & & 6 & & \\
\hline
\end{tabular}

crested blades. Crested blades were produced from different variants of ETF and erratic Cretaceous flint. Some specimens revealed natural and cortical surfaces (e.g. Fig. 4).

Group VI, retouched tools are a diverse part of the inventory (Fig. 7 and Online Resource 6). Most of the tools were made from ETF $(61.90 \%)$ and erratic Cretaceous flint $(33.33 \%)$. The majority of them were made of blade fragments $(38.1 \%)$ and primary/secondary crested blades $(14.3 \%)$. Many of them were also made of flakes $(26.2 \%)$. The most numerous among the retouched tools are retouched blades and retouched flakes. In turn, the most distinctive in this assemblage, common in Magdalenian inventories, are perforators with massive Bec type tips/bits. This group also applies three burins in different variants, two combined tools (burin+perforator) and backed bladelet (Fig. 7d). Among the other tools, we distinguished: truncations, retouched bladelets and one small perforator. Apart from those tools, one hammerflint was found (Online Resource 6: Figure S3).

\section{Technology}

The flint-working technology applied in Stare Baraki was based on the exploitation of single-platform cores. Almost all of the cores made of ETF share common characteristics. These are similar core angles and careful preparation of striking platforms.

All raw materials processed at the site fit the nearby outcrops of ETF and erratic Cretaceous flint (ECF) (see section Raw materials). In the first phase of lithic reduction, a nodule of suitable shape and size was selected. The largest core, which refits with a large removal flake, has natural surfaces (aeolian and stripped cortex) preserved on the side edges of posterior and distal parts (Fig. 4a). Based on its size $(145 \times 54$ $\times 80 \mathrm{~mm})$ and weight $(0.793 \mathrm{~kg})$, size of negatives on cores and comparison of debitage size, we assume that original flint nodules selected for processing could have measured approx. $15 / 20 \mathrm{~cm} \times 12 / 15 \mathrm{~cm} \times 8 / 10 \mathrm{~cm}$ and weighed about $1.5-2 \mathrm{~kg}$. Presumably, they were tabular in shape.

The cores bear traces of classic preparation covering the pre-flaking surface, sides and back parts (Fig. 4a-d and Online Resource 5). The front of the core was faceted on the longer and narrower part of a tabular flint concretion by forming one or two crests. Convex flaking surfaces were preserved on most of the cores, on their narrower sides. Striking platforms were carefully prepared to make an acute-angle with the front. The sides and rear parts of cores were also prepared.

In the next stage of the flint processing the crested or cortical blades were detached from the front of the cores. Blades were detached after careful preparation of the striking platform using the en éperon technique (Pigeot 2004: pp. 6772 ), as evidenced by the traces on cores and blade blanks (Fig. 4c, 5, 6). On double platform cores, the angles are ca. $75^{\circ}-85^{\circ}$ and $85^{\circ}-90^{\circ}$, respectively. In the distal parts of some cores, there are negatives of flakes, detached as a repair procedure, to form a tip of the core and enable further exploitation of flaking faces. It also seems that the presence of the opposed platform on the double platform cores wasn't for exploitation, but for retention of proper proportions of the core (Fig. 4c-d). On flaking faces one can distinguish negatives of short blades/ flakes, usually terminated with a hinged scar, being the probable reason for rejection. In the final phase of exploitation, one of the distinguished cores (made of ECF) was reoriented and adopted for bladelets production (Online Resource 4). The last stage of exploitation is represented by flake cores that were abandoned at the site (Fig. 4 and Online Resource 5).

\section{Blades and bladelets technology analysis}

Blades were subdivided with respect to the raw material into categories: blades made of Świeciechów flint (SW), blades 
Fig. 5 Example of refitted artefacts from Stare Baraki, site 1, made from Turonian flint. Blades show evidence of a crested blade preparation on their dorsal side. On the ventral side there are lips and the spur butts (en éperon)

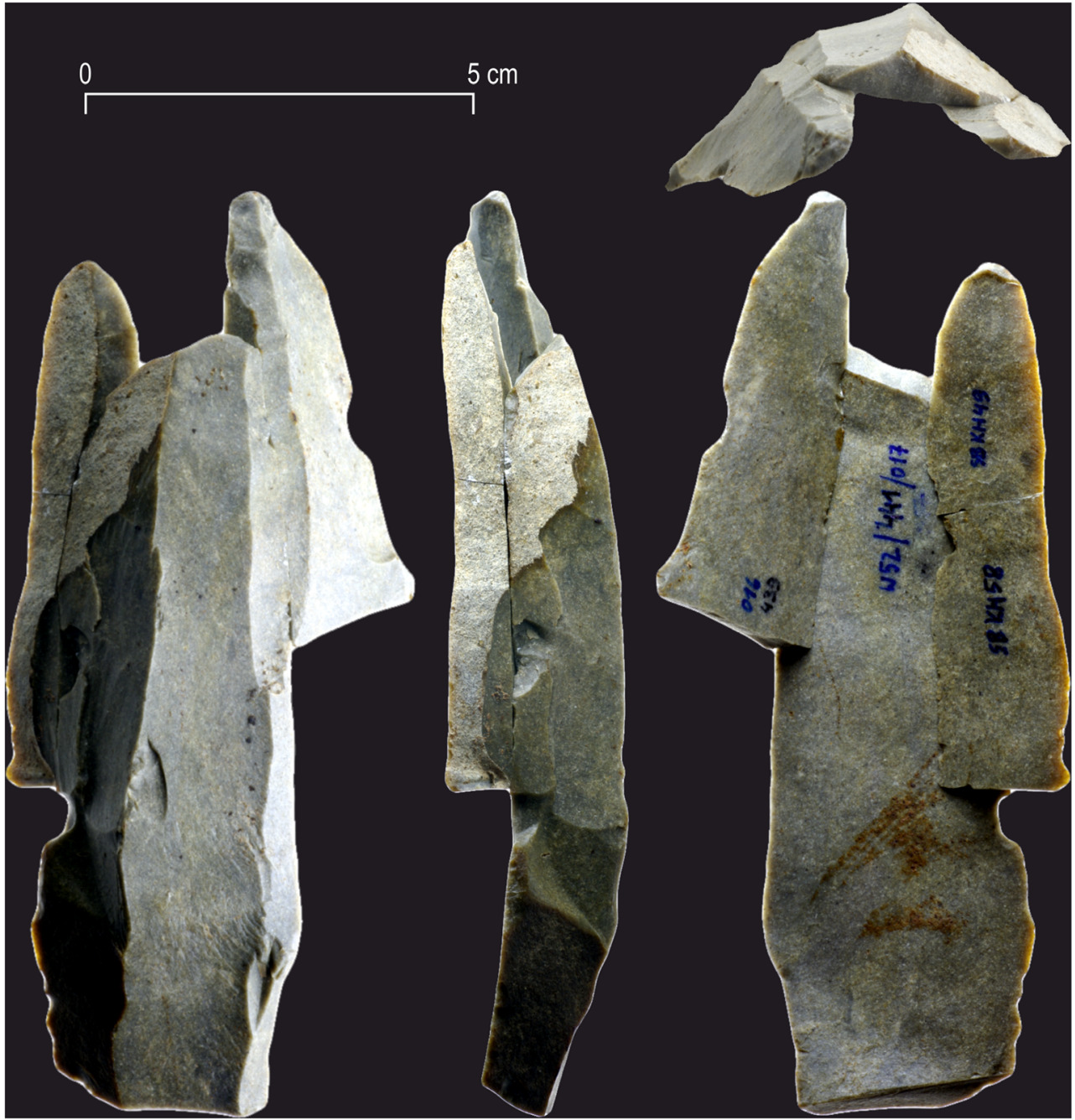

made of Gościeradów flint (GC), blades made of flint resembling the Świeciechów variant $(\sim \mathrm{SW})$ (plain or with scant spots on the siliceous mass), and blades made of erratic Cretaceous flint (ECT).

Detailed results of the analysis of individual blade features are presented in Online Resource 8. This examination helped to determine the techniques employed at Stare Baraki for the detachment of blades and bladelets from cores. The previously conducted analysis (Wiśniewski 2020) involved a significantly smaller sample with no division into raw material categories.

In general, in all ETF variants, we observed remarkable similarities. However, when comparing ETF to ECF, some differences arise (Table 6 and Online Resource 8).

Most prevalent in blades made of ETF are oval/pointed, oval and triangular facetted butts. Their sizes are widely diverse and range between 5.1 and $50 \mathrm{~mm}^{2}$. The application of the en éperon technique was confirmed in $28.4 \%$ of instances (Table 6). The lip formation is also frequent. The flaking angle of most blades ranges between 70 and $89^{\circ}$, with angles of $40-$ $69^{\circ}$ also being common. Bulbs are usually marked or diffused. Nearly half of all analysed blades had no bulbar scars. Characteristic "esquillement $d u$ bulbe" scarring (Pelegrin 2000: pp. 79-80) was recorded in only $7.5 \%$ of ETF blades. On dorsal surfaces, in proximal parts, traces of reduction in the form of pointed negatives or hinges, and pointed negatives and hinges were observed quite frequently (Fig. 6). However, it was often the case that no traces of dorsal reduction were found. Blades are rather irregular (52.9\%), with slightly curved specimens being predominant (88.2\%). Blades with twisted profiles are also quite frequent $(47.7 \%)$. Most blades have feathered and hinged ends. Numerous instances of blade defragmentation were recorded (Online Resources 8).

Such features of blades indicate the application of the direct percussion technique using a soft, organic hammer. Based on experimental research, one cannot exclude the use of indirect percussion or the employment of both techniques (Pyżewicz et al. 2014: p. 76). The most distinctive feature of blade blanks in the discussed assemblage is spur butts (en éperon) 
Fig. 6 Examples of the application of en éperon technique at Stare Baraki: a, c Świeciechów flint ( $\sim \mathrm{SW}), \mathbf{b}, \mathbf{d}, \mathbf{e}$ Gościeradów flint (GC)
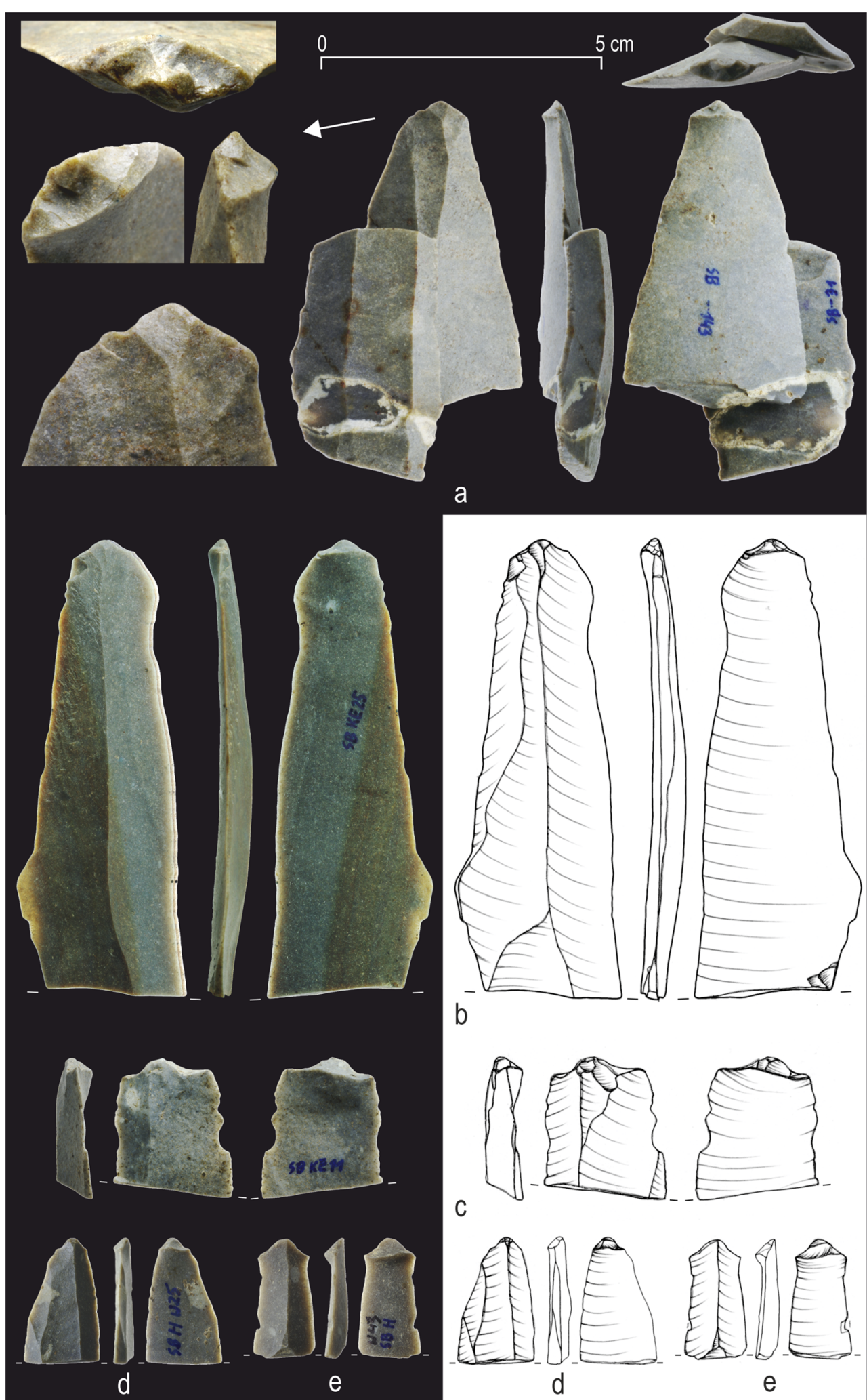

d
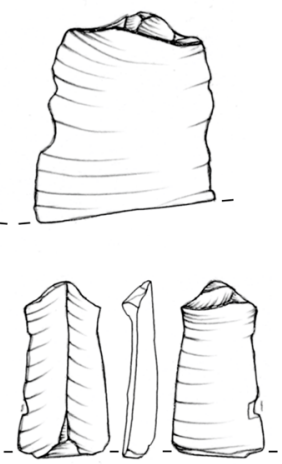

e
(Valentin and Pigeot 2000: p. 134; Surmely and Alix 2005), which are directly connected with en éperon preparation (Figs. 4c, 5, 6). This technique is typical of Magdalenian flint-working and was aimed at obtaining blade blanks
(Pelegrin 2000: p. 78; Pigeot 2004: pp. 67-72; Floss 2012: p. 384; Maier 2015: p. 33).

On the ventral sides of blades, scars known as "esquillement du bulbe" were recorded. They occur on several 
Table 6 Butts type in Stare Baraki (after Inizan et al. 1999)

\begin{tabular}{llllll}
\hline \multirow{2}{*}{ Raw materials } & \multicolumn{2}{l}{ TUR } & & \multicolumn{2}{l}{ ECF } \\
\cline { 2 - 3 } \cline { 5 - 6 } \cline { 5 - 6 } Butt & $N=67$ & $100.0 \%$ & & $N=14$ & $100.0 \%$ \\
\hline Cortical & 0 & 0.0 & 0 & 0.0 \\
Plain & 18 & 26.9 & 7 & 50.0 \\
Dihedral & 2 & 3.0 & 0 & 0.0 \\
Facetted & 18 & 26.9 & & 0 & 0.0 \\
en Chapeau de gendarme & 1 & 1.5 & & 0.0 \\
Winged & 0 & 0.0 & & 7.1 \\
Pecked & 1 & 1.5 & & 0 \\
Spur / »en éperon« & 19 & 28.4 & & 0.0 \\
Linear & 6 & 9.0 & 4 & 0.0 \\
Punctiform & 2 & 3.0 & 2 & 14.3 \\
\hline
\end{tabular}

specimens $(7.5 \%)$ and only in the ETF variant. Even though they are relatively rare, together with other analysed features (Online Resource 8) they may be regarded as an evidence of the direct percussion technique using a "soft" stone hammers (Pelegrin 2000: pp. 79-80; Sano et al. 2011: pp. 1476-1477) It is noteworthy that some experimental studies also showed that the "esquillement du bulbe" may result from the use of antler hammers (Roussel et al. 2009: p. 231).

Blades and bladelets made of ECF exhibit a little bit different features. Irregular and linear smooth butts are definitely the most prevalent. The sizes of most butts do not exceed 5 $\mathrm{mm}^{2}$. The use of the en éperon technique was not confirmed. The lip formation is almost absent. The flaking angle of all blades ranges between 70 and $89^{\circ}$. The majority of specimens have marked bulbs. Bulbar scars were recorded in slightly more than half of all analysed blades. There are no indications of "esquillement du bulbe" scarring. On dorsal surfaces, traces of reduction in the form of pointed negatives and hinges are dominant. Blades are regular $(100 \%)$, with slightly curved specimens being prevalent $(66.7 \%)$. Blades with twisted profiles are as common as those with straight ones. Most blades have feathered and hinged ends. Numerous fragmentations of blades and many complete specimens were recorded.

These features could indicate that blades and bladelets made of ECF were detached through percussion using a "soft" stone hammer (Pelegrin 2000: pp. 79-80). This technique is also connected with several other characteristics. These include small butts of sizes not exceeding $5 \mathrm{~mm}^{2}$, with the striking angle most commonly exceeding $75^{\circ}$, and intensive dorsal reduction. The above-mentioned butt sizes make up $57.1 \%$ of the examined sample. The striking angle was confirmed in the same number of instances. Intensive dorsal reduction was also observed (Online Resource 8).

The striking angle exceeding $75^{\circ}$ and butt sizes not exceeding $5 \mathrm{~mm}^{2}$ are most common on bladelets whose widths do not exceed $10 \mathrm{~mm}$. Most of them were made of ECF (83.3\%). In the majority of cases, a striking angle lower than $75^{\circ}$ and a butt size exceeding $5 \mathrm{~mm}^{2}$ are found on blades whose widths exceed $10 \mathrm{~mm}$. Nearly all of them were produced from ETF (93.8\%).

The only hammerflint discovered so far might be connected with percussion using "soft" stone hammers. Its surface is partially cortical and bears traces of characteristic hammering (Online Resource 5: Figure S3).

\section{Raw materials}

The inventory from Stare Baraki comprised nearly all aforementioned varieties of ETF raw materials, with the exception of black flint. They constitute $85.43 \%$ of the entire raw material structure (Online Resource 6: Table S1). Their contribution is as follows: $16.19 \%$ is Świeciechów flint (SW), $29.55 \%$ is Gościeradów flint (GO), and $39.68 \%$ is grey or light grey flint with sparse whitish spots or without them, which can be a less spotted variety of Świeciechów flint (marked in tables as $\sim$ SW). All above-mentioned variants of Turonian raw materials are now available on the ground surface, within a $20 \mathrm{~km}$ radius around the site. The nearest is Gościeradów flint, whose outcrops occur mainly at a distance of 3-5 km to the northwest of the site. In addition, approx. $7 \mathrm{~km}$ to the south-east of the site, there is another small outcrop of this raw material. The outcrops of Świeciechów flint are located approx. $10 \mathrm{~km}$ and $20 \mathrm{~km}$ to the north-west of the site (Fig. 1b-c).

Apart from Turonian raw materials, the inventory also included artefacts made of ECF (12.96\%). Natural occurrence of this raw material was confirmed on the edge of the Lublin Upland, approx. $1 \mathrm{~km}$ to the south-east of the site. Nodules and pieces of ECF occur within loose Middle Pleistocene glacifluvial sands and gravels (Libera et al. 1991/1992: p. 25, Fig. 4.). Jurassic flint was also distinguished $(1.42 \%, 8$ specimens) among the raw materials used at the site. These specimens are macroscopically similar to some varieties found in the Kraków-Częstochowa Upland. However, during the survey we found natural outcrops of very similar raw material, approx. $7 \mathrm{~km}$ to the south-east of the site. Thus, we consider its local origin. The inventory also comprises artefacts of indeterminate raw material $(0.20 \%)$.

\section{Discussion}

\section{The Turonian flint economy at Stare Baraki}

Unlike other Magdalenian inventories from the area where Turonian raw materials occurred, artefacts from Stare Baraki are not patinated, which facilitated a relatively full identification of the raw material structure of the inventory. It is made up of various types of Turonian flint, outcrops of which are found on the right bank of the Vistula. Deposits of ETF occurring in the proximity of the site comprise various types of siliceous rocks (Figs. 4, 5, 6, 7, and Online Resources 5), 
Fig. 7 Stare Baraki, site 1. Examples of tools made from Turonian flint: a-b becs; c burin; d backed bladelet. Raw materials: a, c Gościeradów flint (GC); b Świeciechów flint ( $\sim \mathrm{SW})$; d erratic Cretaceous flint (ECF)
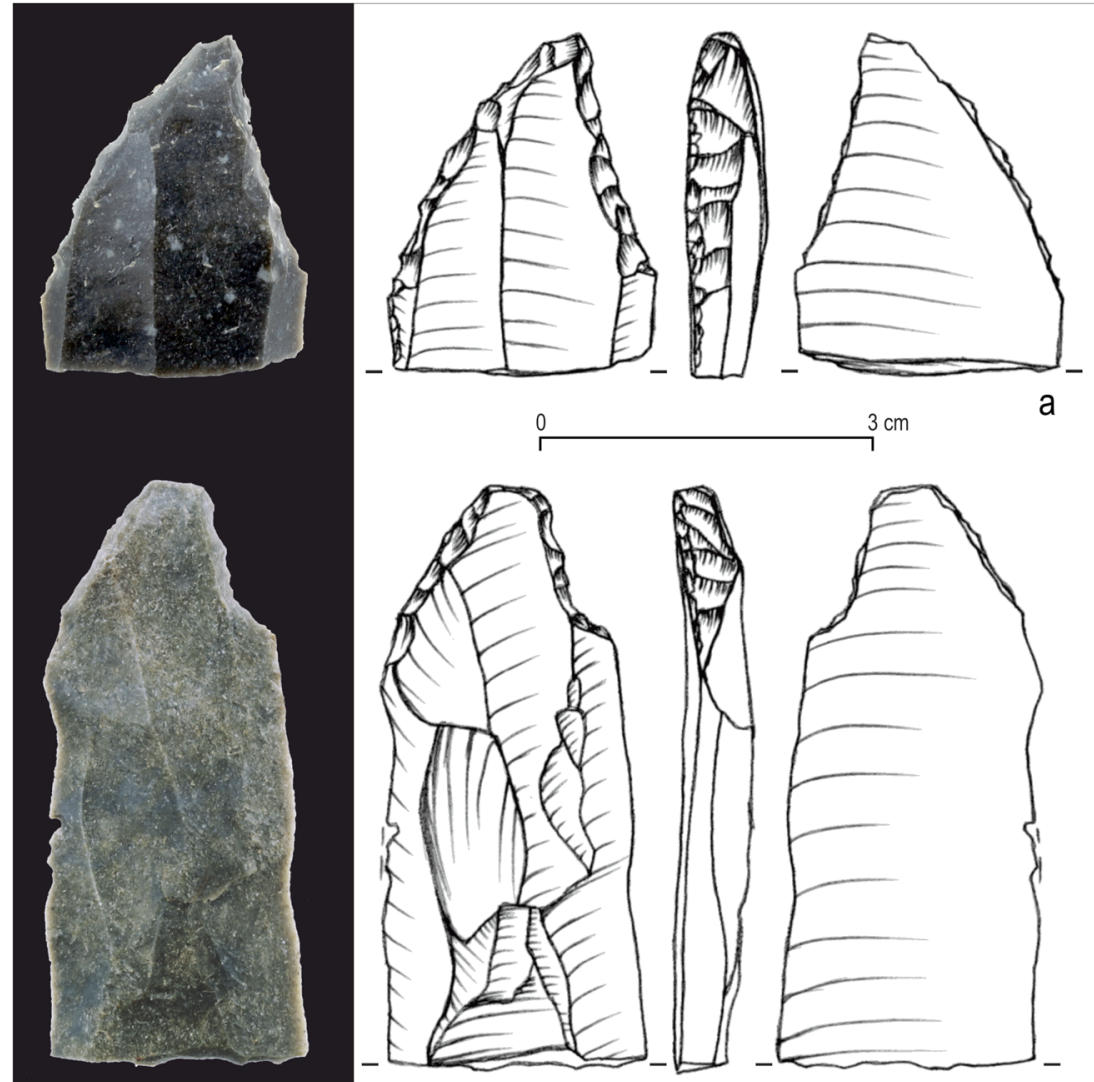

b
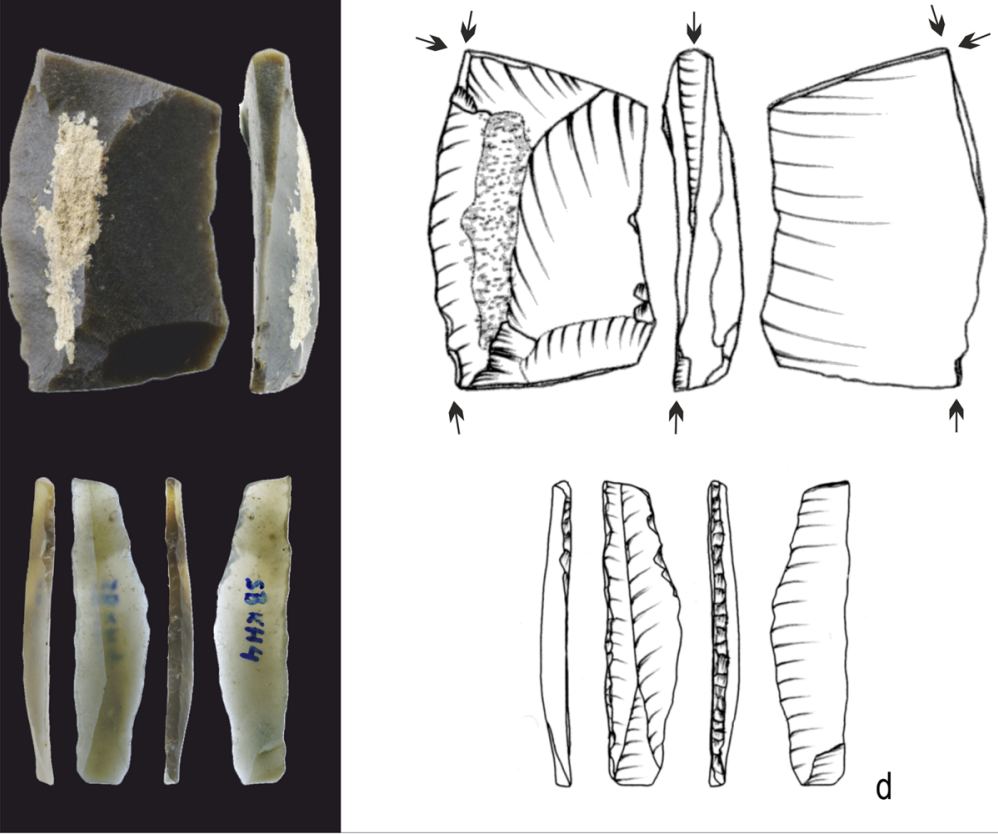

C
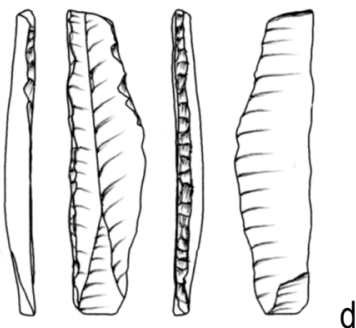

manifested mainly in the concretion size, colour of siliceous mass, and technical properties This wide diversity is enhanced by the occurrence of some of the above-mentioned variants in one nodule (e.g. Fig. 6a). Despite various shapes and sizes of natural flint nodules, most of the ETF varieties displayed high technical properties, providing Magdalenian flint workers with easy access to a wide selection of good quality raw materials. Based on preserved cores, blade blanks and some refittings from Stare Baraki, we were able to estimate sizes of selected concretions (see section Technology). Natural and cortex surfaces occur on some cores, which indicates that flint nodules were procured from exposed regolith or soil. 
Natural nodules of the Świeciechów flint might have been most suitable of all ETF variants available in the area. This raw material is found in large, slab-like unweathered form, and exhibits excellent technical properties. Its occurrence is territorially limited (Fig. 1b-c).

Stare Baraki is a site of a workshop character. Nearly all stages of processing have been identified there, except for activities connected with testing the nodules. These were most likely performed in the procurement area (at the outcrops). All other stages of flint working are recorded at the site, such as early preparation (indicated by cortical and preparation specimens), blade procurement, repair work (chipping off removal and rejuvenation flakes) and tool production. Among six distinguished artefact groups representing individual stages of processing (Online Resource 4), group I connected with early core preparation is the least numerous. Low contribution of cortical flakes to the inventory structure $(4.05 \%)$ might be connected with the fact that pre-cores and cores were brought to the settlement after removal of cortical parts from their surfaces in the course of pre-treatment. This can also be the result of large sizes of the ETF nodules (in particular, of the Świeciechów flint), the intensive exploitation of which resulted in a relatively modest contribution of artefacts with cortical and natural surfaces (see Wilczyce - Schild 2014: p. 174).

The vast majority of cores from this collection are moderately and highly exhausted specimens. They exhibit acute removal angles, the majority of them approximating to $75^{\circ}$. This value is considered as the upper limit enabling effective separation of blade blanks using an organic hammer (Maier 2015: p. 33).

Striking platforms were prepared in a way so as to obtain an isolated point of percussion before blade separation (en éperon preparation). The use of this technique was also confirmed by technological analysis of blades and bladelets. The most distinctive and common feature of blade blanks in the discussed collection are en éperon spur butts, which are directly connected with en éperon preparation. The use of this technique is connected with detaching blades from cores using a soft, organic hammer (Valentin and Pigeot 2000: p. 134; Pelegrin 2000: p. 78; Pigeot 2004: pp. 67-72; Floss 2012: p. 384; Pyżewicz et al. 2014: p. 69).

Blades were also probably detached with the use of a "soft" stone hammer, which is confirmed by the presence of several characteristic features (Online Resource 8).

Generally, production was aimed at relatively long and suitably wide blades. In order to obtain the right partprocessed material, a core had to be prepared appropriately. During exploitation, a suitable core angle had to be sustained by renewing and rejuvenating the striking platform, and by other correcting and repair operations carried out to sustain the right condition of a core. These were time-consuming activities involving a number of successive operations (selecting raw materials within the outcrop - and presumably also pre-processing, transporting obtained raw materials to a determined place and producing blade blanks according to an established pattern - standardised production). Blades (often bent and twisted) were used mostly for the production of tools (burins, perforators etc.). Bladelets (straight), though very sparse in the discussed assemblage, were used mostly for the production of components of throwing weapons (backed bladelets) (Valentin 2008: p. 16).

Apart from blade blanks (long blades used for the production of domestic tools), flint components of hunting weapons were repaired and/or produced at the site. Presence of a backed bladelet and cores used for chipping off bladelets can substantiate the use of these techniques.

Artefacts from Stare Baraki have not been subject to usewear analysis. This analysis was applied to the material from Podgrodzie on the west bank of Vistula (Pyżewicz 2015a), which is similar to that from Stare Baraki. Blade blanks, mainly of Świeciechów flint, were produced there (Pyżewicz et al. 2014). Use-wear analysis indicated that the majority of tools discovered there do not bear traces of intense wear. This could be connected with the fact that activities taken up at that site were short-term. It could also result from easy access to good quality raw materials or frequent repairs aimed at making the tools more effective (Pyżewicz 2015a).

\section{Site function}

Establishing camps along the edge of an upland area enabled observation of valleys frequented by large herds of game. From the viewpoint of hunting strategy, this was obviously an attractive factor in choosing a camp location. The location of the site in Stare Baraki meets this criterion, yet, research conducted at the site indicates its workshop character.

The site could have had two functions. It could have been a well-known vantage point visited by action groups, and at the same time a place where flint raw materials of good quality held for the production of blade blanks were transported from the nearby outcrops. Tools found at the site could have been used during a short stopover and then abandoned (forgotten). Blade blanks were certainly transferred from the site to other locations, like some of the tools produced at the site.

As it was assumed for entire Central European Magdalenian, raw materials in Stare Baraki could have been obtained during the performance of everyday activities near the camp and in the course of seasonal long-distance migrations, for example, from a base camp to a hunting camp (Maier 2015: pp. 88-89). Based on ethnographic research, L. Binford refers to this as embedded procurement strategy (Binford 1979: p. 259). It is also assumed that, in the logistics system of exploitation of this area, in periods when food procurement was less important (after the season of migration of gregarious animals), hunter-gatherers anticipated their needs and "geared up", producing reserves of materials and tools (Floss 2002: p. 86; Jochim 2018: pp. 196-199). 


\section{Age of Magdalenian settlement at Stare Baraki}

The entire sequence of sediments preserved at Stare Baraki records a series of geomorphic events. The lowermost sediments (Unit 3) represent loess accumulation, which most probably started during Last Glacial Maximum and lasts until around $12.6 \pm 1.0 \mathrm{ky} \mathrm{BP}$, as indicated by OSL dates (Table 2 and Online Resource 3). In the Lublin Upland, as well as in the entire Meta-Carpathian zone, an aeolian accumulation during that period produced a thick loess cover (Lanczont and Madeyska 2015). The next stage was erosion, recorded in the bottom of the Subunit $2 \mathrm{~b}$ as a series of erosional channels. That event may record climatic change, i.e., a shift toward more warm and humid conditions, which halted loess accumulation and possibly initiated degradation of permafrost, creating the conditions for solifluction and rill erosion. On the basis of OSL dating and general stratigraphic position, these milder conditions can be linked with Bølling-Allerød Interstadial, of Greenland Interstadial 1 (GI-1), dated to 14.7-12.8 ky BP (Rasmussen et al. 2014). Magdalenian settlement, recorded in the Subunit 2a, followed these erosional events. Presence of the periglacial microstructures within the Magdalenian-bearing unit testifies that the settlement was followed by at least one cold stadial. As the last stadial of the Pleistocene is Younger Dryas (Greenland Stadial 1, GS1), we may assume that Magdalenian settlement at Stare Baraki preceded at least the later part of Younger Dryas, which is consequent with the dating results. According to the Bayesian statistical modelling of the obtained dates (Online Resource 3), Magdalenian settlement at Stare Baraki can be approximated to around $13.3-10.8 \mathrm{ky}$ BP $(68.2 \%)$ or 14.5-10.0 ky BP (95.4\%). These ranges cover both BøllingAllerød Interstadial and Younger Dryas Stadial (as well as the Early Holocene, which can be rejected) and overlap with a duration of the late Magdalenian phase.

\section{Turonian flint in easternmost Magdalenian}

In the eastern zone of Magdalenian settlement, site inventories include two dominant local raw materials of high functional properties: chocolate flint occurring in the northern periphery of the Holy Cross (Świętokrzyskie) Mountains, and various types of Turonian flint discussed here, outcrops of which are located on both banks of the Vistula river (WTF and ETF) (Libera 2002; Wiśniewski 2008).

The way the Turonian flint was exploited by Magdalenian communities here reflects a general settlement pattern adopted in the whole Central European Magdalenian. Their settlement model assumed selection of areas abundant in raw materials of very good quality and situated in the vicinity of large rivers (Maier 2012, 2015). Particularly attractive as locations for individual sites were areas characterised by geodiversity and biodiversity which was conducive to human existence at that time (Hołub et al. 2016). In eastern Poland the sites were located on both banks of the Vistula river, close to the confluence of two large rivers (the Vistula and the San). We can describe this region as a geographic bottleneck - the place where the vast Sandomierz Basin narrows and turns northward into a canyon of the Lesser Poland Vistula Gorge. Analogical situations can be observed in other CEM areas (e.g. the north-western part of the Circum-Jura Group and the western part of the Danube Group; after Maier 2015). The areas near the Vistula and San rivers presumably favoured a specific system of land exploitation, with functionally diverse and interconnected centres. To date, Turonian flint has been recorded at 14 sites (Fig. 1 and Online Resource 1). They vary in size (large and small sites), function (basic camps, hunting camps and workshops) and settlement duration (short and long-term occupation) (Połtowicz-Bobak 2013: p. 167).

The area in question was a part of the Polish-Moravian Group, which was divided into six exploitation zones (Maier 2015). With regard to ranges and directions of the distribution of Turonian materials (ETF in particular), two distinct directions stand out - the north-south and the east-west, the former covering shorter distances (Fig. 1a and Online Resource 1). It is assumed that north-south direction reflects mostly seasonal migrations within one exploitation zone (Maier 2015: pp. 225-226). The east-west long-distance migrations, however, indicate movement from one exploitation zone to another.

ETF distribution in the discussed area, mainly that of the Świeciechów flint, indicates mostly seasonal migrations within one exploitation zone, which can be exemplified by sites in Wilczyce and Klementowice. The inventory from Wilczyce is abundant in regional (local/regional?) raw materials (over $90 \%$ ) obtained within a $20-30 \mathrm{~km}$ radius from the site (Królik 2014: p. 234). This site was interpreted as a basic camp, functioning in winter and early spring (Krajcarz and Krajcarz 2014; Schild 2014). Generally, the management of raw materials in Wilczyce corresponds to the pattern adopted in CEM for sites inhabited in winter (Floss 2002: p. 87). Compared to the inventory from Wilczyce, the contribution of regional (local/regional?) raw materials in Klementowice is a little bit lower. They make up about two-thirds of the raw material structure (a distance of approx. $60 \mathrm{~km}$ ). Transferring the Świeciechów and chocolate flint to the camp was probably connected with seasonal migrations. Based on analysis of faunal remains, it was determined that the site was settled in late summer or early autumn (Wiśniewski et al. 2012b; Nývltová Fišáková 2015).

Discoveries exemplifying the east-west migrations (i.e. migrations from one exploitation zone to another) include blades of Świeciechów flint found in Mosty (Cyrek 1986), in Oelknitz in Thuringia (Ginter 1974; Kozłowski 1987) and in Pekárna Cave in Moravia (Bednarz 1998; Oliva 2002).

As regards CEM, most distances (97\%) referring to the supply of raw materials do not exceed $300 \mathrm{~km}$ in a direct line. 
This value is a threshold distance for the acquisition of raw materials through embedded procurement (Binford 1979: p. 259). It is assumed that raw materials obtained in this way within a $300 \mathrm{~km}$ radius from the site could have been left by directly those hunter-gatherer individuals, who procured them from an outcrop (Maier 2015: p. 89).

Polish lands are abundant in good quality lithic raw materials, which satisfied Magdalenian flint workers' expectations. It is noticeable that in the raw material structure of individual site inventories, good quality raw materials are dominant (Poltowicz-Bobak 2013). Examples of sites which correspond to the general pattern of Magdalenian settlement in CEM include Sowin 7 in Silesia (Wiśniewski et al. 2012a), Kleszczowa in Kraków-Częstochowa Upland (Sudoł-Procyk 2020: in press), Sromowce Wyżne-Katy 1 in the Carpathians (Rydlewski 1989: pp. 51-55), and some sites of the Kraków area Wołowice 1 and Brzoskwinia 7 (Sobczyk 1993). All these sites are situated in the vicinity of outcrops of very good quality lithic raw materials and near rivers. They are often located on land culminations or in places which were good vantage points (Online Resource 9). The site in Stare Baraki is situated in the south-west part of the Lublin Upland, with a view on the Sandomierz Basin. In good weather conditions, visibility from the site extends up to a dozen kilometres across this basin.

Insufficient series of radiocarbon dates of Magdalenian sites in the discussed area still makes it impossible to determine precise time relations between the sites. This problem is partially caused by the weak preservation state of organic material. Bones are preserved very rarely, and charcoals usually lack of context (such as a hearth).

Radiometric data are available for five sites: Wilczyce (Schild 2014), Klementowice (Wiśniewski 2015) and Hłomcza (Lanczont et al. 2002), which are connected with the cold oscillation of the Oldest Dryas (GS-2a), as well as Wierzawice and Mosty, dated to the Allerød interstadial age (GI-1d-c) and representing the latest stage of Magdalenian settlement in the Polish lands (Bobak et al. 2013; Bobak et al. 2017). Results of absolute dating conducted for Stare Baraki provided a wide chronological range and suggest the later phase of the Magdalenian in the Polish lands (Bølling-Allerød interstadial?).

\section{Conclusions}

Materials from Stare Baraki are the only trace of Magdalenian community inside the zone of Turonian flint outcrop on the right bank of the Vistula. Of all flint varieties, the Świeciechów one was of significant importance to Magdalenian communities. The excellent technical properties of this material and favourable location of its outcrop near large rivers (near migration routes of gregarious animals) seem to explain the demand for such flint during the whole late Magdalenian in what is now Poland.
Discoveries made in Stare Baraki provided new data for the reconstruction of land exploitation methods in the eastern part of Magdalenian settlement. Generally, the management of ETF raw materials (mainly Świeciechów flint) reflects the Central European pattern, with its logistics system of settlement with a settlement centre and seasonal camps. Besides the problem of chronological relations between individual sites in the region, it can be assumed that the settlement centre encompassed the area of Turonian flint outcrop (WTF and ETF) with a basic camp in Wilczyce, as well as seasonal ones in Klementowice in the north and Wierzawice (?) in the south, and short-term camps functioning as vantage points and temporary workshops, such as the one in Stare Baraki.

The site in Stare Baraki was certainly a workshop, situated inside the zone of Turonian flint deposits on the right bank of the Vistula river. The location of the settlement enabled excellent visibility across the vast basin. The presence of a set of domestic tools of limited diversity indicates that it was a temporary camp, which might have been visited repeatedly. Procurement of raw materials in Stare Baraki could have taken place while performing everyday activities and/or during seasonal migrations at longer distances. They could also have been acquired while gearing up for anticipated needs (Floss 2002: p. 86; Maier 2015: pp. 88-89; Jochim 2018: pp. 196199). Standardised flint production required time, skills and good quality materials (Fisher 2002: p. 61), and was aimed at relatively long and suitably wide blades or bladelets.

Our research has yielded information on the stratigraphy and chronology of the site. These findings, however, are preliminary and require further verification.

Supplementary Information The online version contains supplementary material available at https://doi.org/10.1007/s12520-020-01230-y.

Acknowledgements We are thankful to Jerzy Libera for consulting our materials; to Magdalena Moskal-del Hoyo for taxonomic identification of charcoal fragments; to Michał Przeździecki, Marta Połtowicz-Bobak, Dariusz Bobak and Katarzyna Pyżewicz for providing information on archaeological materials from Ćmielów-Mały Gawroniec, Wierzawice and Podgrodzie; and to Jacek A. Tomaszewski and Witold Grużdź for making the materials stored in the National Archaeological Museum in Warsaw available for this study.

Funding This study was funded by the National Science Centre, Poland, grant no. 2014/15/N/HS3/01766 awarded to Tadeusz Wiśniewski.

\section{Compliance with ethical standards}

Conflicts of interest The authors declare that they have no conflict of interest.

Open Access This article is licensed under a Creative Commons Attribution 4.0 International License, which permits use, sharing, adaptation, distribution and reproduction in any medium or format, as long as you give appropriate credit to the original author(s) and the source, provide a link to the Creative Commons licence, and indicate if changes were made. The images or other third party material in this article 
are included in the article's Creative Commons licence, unless indicated otherwise in a credit line to the material. If material is not included in the article's Creative Commons licence and your intended use is not permitted by statutory regulation or exceeds the permitted use, you will need to obtain permission directly from the copyright holder. To view a copy of this licence, visit http://creativecommons.org/licenses/by/4.0/.

\section{References}

Adamiec G, Aitken MJ (1998) Dose-rate conversion factors: update. Ancient TL 16(2):37-50

Balcer B (1971) kopalnia krzemienia w Świeciechowie-Lasku, pow. Kraśnik w świetle badań 1967 r. Wiadomości Archeologiczne 36(1):71-132

Balcer B (1975) Krzemień świeciechowski w kulturze pucharów lejkowatych - eksploatacja. obróbka i rozprzestrzenienie, Wrocław

Bednarz M (1998) Polskie surowce krzemienne w materiałach magdaleńskich z Morawskiego Krasu. Światowit XLI, Fasc. B: 307-322.

Bielecka M (1968) Objaśnienia do Szczegółowej Mapy Geologicznej Polski w skali 1:50 000, arkusz Zaklików (M34-35C). Wydawnictwa Geologiczne, Warszawa

Binford LR (1979) Organization and formation processes: looking at curated technologies. J Anthropol Res 35(3):255-273

Bobak D, Połtowicz-Bobak M (2014) Bayesian age modelling of the Magdalenian settlement in the territory of present-day Poland. Recherches Archéologiques, Nouvelle Serie 5-6:51-67

Bobak D, Połtowicz-Bobak M (2018) Variability of the lithic raw material in the Upper and Late Palaeolithic sites in Southeastern Poland. Archaeologia Polona 56:11-21. https://doi.org/10.23858/APa56. 2018.001

Bobak D, Łanczont M, Nowak A, Połtowicz-Bobak M, Tokarczyk S (2010) Wierzawice, st. 31 - nowy ślad osadnictwa magdaleńskiego w Polsce południowo wschodniej. Materiały i Sprawozdania Rzeszowskiego Ośrodka Archeologicznego 31:6378

Bobak D, Płonka T, Połtowicz-Bobak M, Wiśniewski A (2013) New chronological data for Weichselian sites from Poland and their implications for Palaeolithic. Quat Int 296:23-36

Bobak D, Łanczont M, Mroczek P, Połtowicz-Bobak M, Nowak A, Kufel-Diakowska B, Kusiak J, Standzikowski K (2017) Magdalenian settlement on the edge of the loess island: a case study from the northern foreland of the Carpathians (SE Poland). Quat Int 438:158-173

Boroń T, Królik H, Kowalski T (2014) Female Figurines. In: Wilczyce SR (ed) A late Magdalenian winter hunting camp in southern Poland. Institute of Archaeology and Ethnology Polish Adacemy of Sciences, Warszawa, pp 319-333

Brock F, Higham T, Ditchfield P, Ramsey CB (2010) Current pretreatment methods for AMS radiocarbon dating at the Oxford Radiocarbon Accelerator Unit (ORAU). Radiocarbon 52(1):103112

Bronk Ramsey C (2008) Deposition models for chronological records. Quat Sci Rev 27:42-60. https://doi.org/10.1016/j.quascirev.2007. 01.019

Bronk Ramsey C (2009) Bayesian analysis of radiocarbon dates. Radiocarbon 51(1):337-360

Bronk Ramsey C (2017) Methods for summarizing radiocarbon datasets. Radiocarbon 59(2):1809-1833

Bronk Ramsey C, Scott M, van der Plicht H (2013) Calibration for Archaeological and Environmental Terrestrial Samples in the Time
Range 26-50 ka cal BP. Radiocarbon 55(4):2021-2027. https://doi. org/10.2458/azu js_rc.55.16935

Budziszewski J (1986) Exploration oftheminingfield 'Zagarncarzami' in Ożarów, Tarnobrzegvoivodship. Preliminary report. In Biró KT (ed) Papers for the Ist International Conference on Prehistoric Flint Mining and Lithic Raw Material Identification in the Carpathian Basin. Budapest - Sümeg, 20-22 May, 1986, vol (1):69-82. Budapest.

Budziszewski J, Grużdź W (2014) Kopalnia krzemienia w Ożarowie, stanowisko „Za Garncarzami”, w świetle dawnych i nowych badań. In: Piotrowska D, Piotrowski W, Kaptur K, Jedynak A (eds), Górnictwo z epoki kamienia: Krzemionki - Polska Europa. W 90. rocznicę odkrycia kopalni w Krzemionkach / Stone Age mining: Krzemionki - Poland - Europe. On the ninetieth anniversary of the discovery of the Krzemionki mine (series: Silex et Ferrum, vol. 1). Historical and Archaeological Museum in Ostrowiec Świętokrzyski. Ostrowiec Świętokrzyski, pp 147-166.

Cyrek K (1986) Magdaleńskie obozowisko w Górach Świętokrzyskich (Mosty, stanowisko 13). Acta Archaeol Carpathica 25:11-55

Demars P-Y, Laurent P (1989) Types d'outils lithiques du Paléolithique supérieur en Europe. Cahiers du Quaternaire 14. Paris.

Domański M, Webb JA (2000) Flaking properties, petrology and use of Polish flint. Antiquity 74(286):822-832. https://doi.org/10.1017/ S0003598X00060476

Domański M, Webb JA, Glaisher R, Gurba J, Libera J, Zakościelna A (2009) Heat treament of Polish flints. J Archaeol Sci 36:1400-1408

Dondeyne S, Deckers JA (2019) The ABC soil types: podzoluvisols, albeluvisols or retisols? In: Deák J., Ampe C. and Mikkelsen J. (Eds.), Soils as records of past and present. From soil surveys to archaeological sites: research strategies for interpreting soil characteristics. Proceedings of the Geoarchaeological Meeting, Bruges, 6 \& 7 November 2019. Raakvlak, Bruges. https://doi.org/10.5281/ zenodo.3420213.

Fedorowicz S, Łanczont M, Mroczek P, Bogucki A, Standzikowski K, Moska P, Kusiak J, Bluszcz A (2018) Luminescence dating of the Volochysk section - a key Podolian loess site (Ukraine). Geol Q 62(3):729-744

Fiedorczuk J, Bratlund B, Kolstrup E, Schild R (2007) Late Magdalenian feminine flint plaquettes from Poland. Antiquity 8:97-105

Fisher LE (2002) Retooling and raw material economies: technological change in late glacial and early postglacial Southern Germany. In: Fisher LE, Eriksen BV (eds) Lithic Raw Material Economy in Late Glacial and Early Postglacial Western Europe. Archaeopress, British Archaeological Reports S1093, pp 53-78.

Fisher LE, Eriksen BV (eds) (2002) Lithic raw material economy in Late Glacial and Early Postglacial Western Europe. Archaeopress, Br Archaeol Rep S1093.

Florek M, Libera J (1994) Pierwszy sezon badawczy przykopalnianych pracowni w rejonie wychodni krzemienia świeciechowskiego w Kopcu. In: Gurba J (ed) Sprawozdania z badań terenowych Katedry Archeologii UMCS w 1993 roku. Wydawnictwo Uniwersytetu Marii Curie-Skłodowskiej w Lublinie. Katedra Archeologii, pp 3-14.

Floss H (2002) Climate and raw material behavior: a case study from Late Pleistocene hunter-gatherers in middle rhine area of Germany. In: Fisher EL, Eriksen BV (eds) Lithic Raw Material Economies in Late Glacial and Early Postglacial Europe. BAR Int Series 1093:79-88

Floss H (2012) Grundformerzeugung im Magdalénien. In: Floss H (ed): Steinartefakte vom Altpaläolithikum bis in die Neuzeit. Tübingen, pp 379-388.

Floss H (2014) Rivers as orientation axes for migrations, raw material transport and exchange in the upper palaeolithic of Central Europe. In: Yamada M, Ono A (eds), Lithic raw material exploitation and circulation in prehistory. A comparative perspective in diverse palaeoenvironments. ERAUL 138:11-22. Liège. 
Geological Map of Poland without Cenosoic Deposits, 1:1 000000 (2000). Dadlez R, Marek S, Pokorski J (eds). Ministerstwo Środowiska and Państwowy Instytut Geologiczny, Warszawa.

Ginter B (1974) Wydobywanie, przetwórstwo i dystrybucja surowców i wyrobów krzemiennych w schyłkowym paleolicie północnej części Europy Środkowej. Przegląd Archeologiczny 22:5-122

Goslar T, Czernik J, Goslar E (2004) Low-energy 14C AMS in Poznań Radiocarbon Laboratory, Poland. In: Nuclear instruments and methods in physics research, section B: beam interactions with materials and atoms 223:5-11.

Gurba J (1970) Historia ukryta w ziemi. (Z przeszłości powiatu kraśnickiego). Kalendarz Lubelski 1970. Wydawnictwo Lubelskie. Lublin, pp 258-263.

Hołub B, Lanczont M, Madeyska T (2016) Examples of landscape reconstructions near the eastern range of the Magdalenian occupation (SE Poland) based on GIS analysis. Anthropol - Int J Human Divers Evol LIV/3:205-230

Inizan M-L, Reduron-Ballinger M, Roche H, Tixier J (1999) Technology and terminology of knapped stone. Préhistoire de la Pierre Taillée 5. Published by Cercle de recherches et d'études préhistoriques. Nanterre.

Jochim M (2018) Environmental change and technological convergence in Southern Germany. In: Robinson E, Sellet F (eds) Lithic technological organization and paleoenvironmental change. Global and diachronic perspectives. Studies in human ecology and adaptation 9, pp 189-202. DOI https://doi.org/10.1007/978-3-319-64407-3 9

Kondracki J (2009) Geografia regionalna Polski. Wydawnictwo Naukowe PWN, Warszawa

Kozłowski JK (1987) Le Magdalénien en Pologne. In: Rigaud JP (ed) Le Magdalénien en Europe, 38th edn. ERAUL, Liège, pp 31-49

Kozłowski SK, Połtowicz-Bobak M, Bobak D, Terberger T (2012) New information from Maszycka Cave and the Late Glacial recolonisation of Central Europe. Quat Int 272-273:288-296

Krajcarz M, Krajcarz M (2014) Summers and Winters at Wilczyce. Seasonal changes of Paleolithic settlement and environment on the basis of seasonality and isotope analysis of animal teeth. In: Wilczyce SR (ed) A late Magdalenian winter hunting camp in southern Poland. Institute of Archaeology and Ethnology Polish Adacemy of Sciences, Warszawa, pp 141-154

Krajcarz MT, Kot M, Pavlenok K, Fedorowicz S, Krajcarz M, Lazarev SY, Mroczek P, Radzhabov A, Shnaider S, Szymanek M, Szymczak K (2016) Middle Paleolithic sites of Katta Sai in western Tian Shan piedmont, Central Asiatic loess zone: Geoarchaeological investigation of the site formation and the integrity of the lithic assemblages. Quat Int 399:136-150. https://doi.org/10.1016/j.quaint.2015.07.051

Król P, Migaszewski ZM (2009) Rodzaje, występowanie i geneza krzemieni. Zarys Problematyki. In: Król P (ed) Historia krzemienia. Muzeum Narodowe w Kielcach. Kielce, pp 12-45.

Królik H (2014) Chipped flint and quartzite artifacts. In: Wilczyce SR (ed) A late Magdalenian winter hunting camp in southern Poland. Institute of Archaeology and Ethnology Polish Adacemy of Sciences, Warszawa, pp 173-240

Krukowski S (1920) Pierwociny krzemieniarskie górnictwa, transportu i handlu w holocenie Polski. Wnioski z właściwości surowców i wyrobów, Część I. Wiadomości Archeologiczne 5:185-206

Krzak Z (1965) Tymczasowa charakterystyka kopalni krzemienia w Świeciechowie. Archeologia Polski, vol (10). No 1:217-233

Krzak Z (1970) Wstępna charakterystyka kopalni krzemienia w Ożarowie Opatowskim. Archeologia Polski, vol 15:291-303

Łanczont M, Madeyska T (eds) (2015) Paleolityczna ekumena strefy pery- i metakarpackiej. Wydawnictwo Uniwersytetu Marii CurieSkłodowskiej, Lublin

Łanczont M, Madeyska T, Muzyczuk A, Valde-Nowak P (2002) Hłomcza - stanowisko kultury magdaleńskiej w Karpatach polskich. In: Gancarski J (ed) Starsza i środkowa epoka kamienia w Karpatach polskich. Krosno, pp 147-188.
Łaptaś A, Mitura P, Muzyczuk A, Olszewska B, Paszkowski M, ValdeNowak P (2002) Krzemień z Birczy. In: Gancarski J (ed) Geologia i wykorzystywanie w pradziejach. Starsza i środkowa epoka kamienia w Karpatach polskich, Krosno, pp 315-338

Leesch D, Müller W, Nielsen E, Bullinger J (2012) The Magdalenian in Switzerland: re-colonization of a newly accessible landscape. Quat Int 272-273:191-208

Libera J (1995) Późny paleolit i mezolit środkowowschodniej Polski. Część pierwsza. Analiza. Lubelskie Materiały Archeologiczne IX. Wydawnictwo Uniwersytetu Marii Curie-Skłodowskiej w Lublinie, Lublin

Libera J (1998) Późny paleolit i mezolit środkowowschodniej Polski. Część druga. Źródła. Lubelskie Materiały Archeologiczne XI. Wydawnictwo Uniwersytetu Marii Curie-Skłodowskiej w Lublinie, Lublin

Libera J (2002) Wykorzystanie krzemienia świeciechowskiego i gościeradowskiego $\mathrm{w}$ paleolicie schyłkowym i mezolicie $\mathrm{w}$ międzyrzeczu Wisły i Bugu oraz w dorzeczu Sanu (zarys problematyki). In: Matraszek B, Sałaciński S (eds): Krze $\neg$ mień świeciechowski w pradziejach. Materiały konferencyjne, Rynia, Maj 22-24, 2000. Studia nad Gospodarką Surowcami Krzemiennymi w Pradziejach 4. Warszawa, pp 29-49.

Libera J, Zakościelna A (2002) Złoża krzemieni turońskich w przełomowym odcinku Wisły. In: B. Matraszek, S. Sałaciński (Eds.): Krzemień świeciechowski w pradziejach. Materiały konferencyjne, Rynia, Maj 22-24, 2000. Studia nad Gospodarką Surowcami Krzemiennymi w Pradziejach 4. Warszawa, pp 93-109.

Libera J, Zakościelna A (2019) Prace terenowe. In: Libera J, Zakościelna A Kopiec 4 i 8, Kosin 10 - pracownie kultury łużyckiej na terenie wychodni krzemieni turońskich w Antyklinie Rachowa. Wydawnictwo Uniwersytetu Marii Curie-Skłodowskiej w Lublinie. Lublin, pp 11-35

Libera J, Zakościelna A, Superson J (1991/1992) Wyniki badań powierzchniowych nad środkową Karasiówką w północnej części Kotliny Sandomierskiej. Annales Universitatis Mariae CurieSklodowska, Sectio F XLVI/XLVII(2):17-57

Maier A (2012) Regional groups and social interaction during the Central European Magdalenian. Notae Praehistoricae 32:121-132

Maier A (2015) The Central European Magdalenian: regional diversity and internal variability. Springer, New York.

Michniak R (1989) Nazewnictwo, geneza, występowanie krzemieni. Prz Geol 37(9):452-458

Migal M (2008) Osadnictwo paleolityczne I mezolityczne mikroregionu Czyżówki, woj. świętokrzyskie. Praca magisterska na kierunku Archeologia w zakresie arch. pradziejowa, Warszawa

Morley MW, Goldberg P, Sutikna T, Tocheri MW, Prinsloo LC, Jatmiko Wayhu Saptomo E, Wasisto S, Roberts RG (2017) Initial micromorphological results from Liang Bua, Flores (Indonesia): site formation processes and hominin activities at the type locality of Homo floresiensis. J Archaeol Sci 77:125-142

Mroczek P (2018) Late Vistulian-Holocene evolution of loess luvisols from the South Polish uplands recorded in micromorphology. Wydawnictwo Uniwersytetu Marii Curie-Skłodowskiej, Lublin

Murray AS, Wintle AG (2000) Luminescence dating of quartz using an improved single-aliquot regenerative-dose protocol. Radiat Meas 32:57-73

Nelson MS, Gray HJ, Johnson JA, Rittenour TM, Feathers JK, Mahan SA (2015) User guide for luminescence sampling in archaeological and geological contexts. Adv Archaeol Pract 3(2):166-177. https://doi. org/10.7183/2326-3768.3.2.166

Nývltová Fišáková M (2015) The Seasonality of the open-air Magdalenian site in Klementowice. In: Wiśniewski T (ed) Klementowice. A Magdalenian site in eastern Poland. Institute of Archaeology Maria Curie-Skłodowska University in Lublin, Lublin, pp 305-307 
Oliva M (2002) Využívání krajiny a zdrojů kamenných surovin v mladém paleolitu Českých zemí. Archeologické Rozhledy LIV/3: 555-581 Archeologický ústav AV ČR

Olive M, Pigeot N, Bignon-Lau O (2019) Un campement magdalénien à Étiolles (Essonne). Gallia Préhistoire [En ligne], 59, mis en ligne le 29 août 2019, consulté le 06 septembre 2019. https://doi.org/10. 4000/galliap.1492.

Pelegrin J (2000) Les techniques de débitage laminaire au Tardiglaciaire: critères de diagnose et quelques réflexions. In: Valentin B, Bodu P, Christensen M (eds) L'Europe centrale et septentrionale au Tardiglaciaire. Confrontation des modèles régionaux de peuplement. Table-Ronde internationale de Nemours, 13-16 may, 1997. Mémoires du Musée de Préhistoire d'lle de France 7, Paris, pp $73-86$

Pigeot N (2004) Les derniers magdaleniens d'Etiolles. Perspectives culturelles et paleohistoriques. XXXVII suplement Gallia Préhistoire, Paris

Połtowicz-Bobak M (2013) Wschodnia prowincja magdalenienu. Wydawnictwo Uniwersytetu Rzeszowskiego, Rzeszów

Połtowicz-Bobak M (2016) On the peripheries of the Magdalenian world. Magdalenian hunters north of the Carpathian and Sudety Mountains. In: J. Kabaciński (Ed.): 500,000 - 5,500 BC. The Past Societes. Polish lands from the first evidence of human presence to the early Middle Ages. Institute of Archaeology and Ethnology, Polish Academy of Sciences. Warszawa, pp 129-152.

Poręba G, Śnieszko Z, Moska P, Mroczek P, Malik I (2019) Interpretation of soil erosion in a Polish loess area using OSL, ${ }^{137} \mathrm{Cs},{ }^{210} \mathrm{~Pb}_{\mathrm{ex}}$, dendrochronology and micromorphology - case study: Biedrzykowice site (S Poland). Geochronometria 46:57-78. https://doi.org/10.1515/geochr-2015-0109

Pożaryski W (1948) Jura i kreda między Radomiem, Zawichostem i Kraśnikiem. Biuletyn Pań-stwowego Instytutu Geologicznego 46. Wydawnictwo Państwowego Instytutu Geologicznego, Warszawa.

Pożaryski W (1953) Plejstocen w przełomie Wisły przez wyżyny południowe. Pr Inst Geol 9:1-134

Přichystal A (2010) Classification of lithic raw materials used for prehistoric chipped artefacts in general and siliceous sediments (silicites) in particular: the Czech proposal. Archeometriai Mühely 3:177-181

Přichystal A (2013) Lithic raw materials in Prehistoric Times of Eastern Central Europe. Masaryk University, Brno

Przeździecki M, Migal W, Krajcarz M, Pyżewicz K (2011a) Ćmielów, st. 95 („Mały Gawroniec”), woj. świętokrzyskie. Badania w roku 2009. Światowit 8(49) (2009-2010)(B), pp 191-193.

Przeździecki M, Migal W, Pyżewicz K (2011b) Badania nad osadnictwem paleolitycznym północnego obrzeżenia Wyżyny Sandomierskiej. Światowit VIII(XLIX) (2009-2010)(B), pp 27-34.

Przeździecki M, Migal W, Krajcarz M, Pyżewicz K (2012) Obozowisko kultury magdaleńskiej na stanowisku 95, Mały Gawroniec" w Ćmielowie, pow. ostrowiecki, woj. świętokrzyskie. Światowit VII(XLVIII) (2006-2008)(B), pp 25-234.

Pyżewicz K (2015a) Biographies of Magdalenian lithic tools from Poland. An in-depth look at two cases from the Kielecka Upland. Anthropol - Int J Human Divers Evol LIII/3:519-529

Pyżewicz K (2015b) The use-wear analysis of the artefacts found at the Magdalenian site in Klementowice. In: Wiśniewski T (ed) Klementowice. A Magdalenian site in eastern Poland. Instytut Archeologii Uniwersytetu Marii Curie-Skłodowskiej w Lublinie. Lublin, pp 184-214.

Pyżewicz K, Migal W, Grużdź W (2014) Magdalenian blade technology from the northeastern European perspective. In: Riede F, Tallavaara $M$ (eds) Lateglacial and postglacial pioneers in northern Europe. BAR International Series 2599, pp 67-78.

Ralska-Jasiewiczowa M, Latałowa M, Wasylikowa K, Tobolski K, Madeyska E, Wright HJ et al. (eds) (2004) Late Glacial and Holocene history of vegetation in Poland based on isopollen maps.
W. Szafer Institute of Botany, Polish Academy of Sciences, Kraków.

Rasmussen SO, Bigler M, Blockley SP, Blunier T, Buchardt SL, Clausen HB, Cvijanovic I, Dahl-Jensen D, Johnsen SJ, Fischer H, Gkinis V, Guillevic M, Hoek WZ, Lowe JJ, Pedro JB, Popp T, Seierstad IK, Steffensen JP, Svensson AM, Vallelonga P, Vinther BM, Walker MJC, Wheatley JJ, Winstrup M (2014) A stratigraphic framework for abrupt climatic changes during the Last Glacial period based on three synchronized Greenland ice-core records: refining and extending the INTIMATE event stratigraphy. Quat Sci Rev 106:14-28. https://doi.org/10.1016/j.quascirev.2014.09.007

Reimer PJ, Bard E, Bayliss A, Beck JW, Blackwell PG, Bronk Ramsey C, Grootes PM, Guilderson TP, Haflidason H, Hajdas I, Hatté C, Heaton TJ, Hoffmann DL, Hogg AG, Hughen KA, Kaiser KF, Kromer B, Manning SW, Niu M, Reimer RW, Richards DA, Scott EM, Southon JR, Staff RA, Turney CSM, van der Plicht J (2013) IntCal13 and Marine13 radiocarbon age calibration curves 0-50,000 years cal BP. Radiocarbon 55(4):1869-1887. https://doi.org/10. 2458/azu_js_rc.55.16947

Rensink E (1995) On Magdalenian mobility and land use in north-west Europe. Some methodologica considerations. Archaeological Dialogues 22:85-119

Roussel M, Bourguignon L, Soressi M (2009) Identification par l'expérimentation de la percussion aupercuteur de calcaire au Paléolithique moyen: le cas du façonnage des racloirs bifaciaux Quina de Chez Pinaud (Jonzac, Charente-Maritime). Bulletin de la Société préhistorique française, tome 106(2):219-238. https://doi. org/10.3406/bspf.2009.13846

Rydlewski J (1989) Pienińskie złoża radiolarytu i ich eksploatacja w epoce kamienia i wczesnej epoce brązu na Podhalu. Acta Archaeologica Carpathica 28:25-80

Samsonowicz J (1924) Odkrycie pierwotnych złóż krzemienia szarego, biało nakrapianego. Wiadomości Archeologiczne 9:99-101

Sano K, Maier A, Heidenreich SM (2011) Bois Laiterie revisited: functional, morphological and technological analysis of a Late Glacial hunting camp in north-western Europe. J Archaeol Sci 38:14681484

Schild R (1980) Introduction to dynamic technological analysis of chipped stone assemblages. In: Plater K (ed) Unconventional archaeology: new approaches and goals in Polish archaeology. Wydawnictwo Polskiej Akademii Nauk, pp 57-87.

Schild R (ed) (2014) Wilczyce. A late Magdalenian winter hunting camp in southern Poland. Institute of Archaeology and Ethnology Polish Academy of Sciences. Warszawa.

Smalley IJ, Bentley SP, Markovic SB (2016) Loess and fragipans: development of polygonal-crack-network structures in fragipan horizons in loess ground. Quat Int 399:228-233. https://doi.org/10.1016/j. quaint.2015.01.034

Sobczyk K (1993) The Late Palaeolithic Flint Workshops at Brzoskwinia-Krzemionki near Kraków. Prace Archeologiczne 55.

Sørensen M (2006) The Chaîne Opératoire applied to arctic archaeology. In: Arneborg J, Grønnow B (eds) Dynamics of Northern Societies. The Danish National Museum. Studies in Archaeology and History, pp 31-44.

Sørensen M (2008) Spatial analysis by dynamic technological classification: a case study from the Palaeolithic - Mesolithic transition in Scandinavia. In: Sørensen M, Desrosiers P (eds) Technology in archaeology: Proceedings from the Sila workshop: the study of technology as a method for gaining insight into social and cultural aspects of prehistory. the Danish National Museum. Studies in Archaeology and History, pp 107-125.

Stoops G (2003) Guidelines for analysis and description of soil and regolith thin sections. Soil Science Society of America Inc., Wisconsin

Stoops G (2008) Micromorphology. In: Chesworth W (ed) Encyclopedia of soil science. Springer, Dordrecht, Berlin, Heidelberg, New York, pp $457-466$ 
Stoops G, Marcelino V, Mees F (eds) (2010) Interpretation of micromorphological features of soils and regoliths. Elsevier, Amsterdam

Street M, Jöris O, Turner E (2012) Magdalenian settlement in the German Rhineland - an update. Quat Int 272-273:231-250

Sudoł-Procyk M (2020) Magdalenian settlement in the south-eastern part of the Ryczów Upland (Polish Jura). New data and the importance of the region. Anthropol - Int J Human Divers Evol LVIII/2-3:285302. https://doi.org/10.26720/anthro.20.06.12.1

Sulgostowska Z (1989) Prahistoria międzyrzecza Wisły, Niemna i Dniestru u schyłku plejstocenu. Państwowe Wydawnictwo Naukowe, Warszawa

Sulgostowska Z (2005) Kontakty społeczności późnopaleolitycznych i mezolitycznych między Odrą, Dźwiną i górnym Dniestrem: studium dystrybucji wytworów ze skał krzemionkowych. Instytut Archeologii i Etnologii Polskiej Akademii Nauk, Warszawa

Surmely F, Alix P (2005) Note sur les talons en éperon du Protomagdalénien. Paléo 17:157-176

Świdrowska J (2007) Kreda w regionie lubelskim - sedymentacja i jej tektoniczne uwarunkowania. Biuletyn Państwowego Instytutu Geologicznego 422:63-78

Szeliga M, Huber M (2016) Mineralogical and petrographic characteristic of basic types of Turonian flints from the north-eastern margin of the Holy Cross Mountains: a preliminary report. Archaeol Polona 54: 83-97

Szymański W, Skiba M, Skiba S (2011) Fragipan horizon degradation and bleached tongues formation in Albeluvisols of the Carpathian Foothills, Poland. Geoderma 167-168:340-350. https://doi.org/10. 1016/j.geoderma.2011.07.007

Valentin B (2008) Magdalenian and Azilian lithic productions in the Paris Basin: disappearance of a programmed economy. The Arkeotek Journal 2(3): 1-54

Valentin B, Pigeot N (2000) Eléments pour une chronologie des occupations magdaléniennes dans le Bassin parisien. In: B. Valentin, P. Bodu, M. Christensen (eds) L'Europe centrale et septentrionale au Tardiglaciaire. Confrontation des modèles régionaux de peuplement. Table-Ronde internationale de Nemours, 13-16 may, 1997. Mémoires du Musée de Préhistoire d'lle de France 7. Paris, pp. 73-86.

Valoch K (2009) Magdalénien na Morave - po padesáti letech. Acta Musei Moraviae. Scientiae Sociales 94:3-37

Van Vliet-Lanoë B, Fox CA, Gubin SV (2004a) Micromorphology of cryosols (Chapter 2). In: Kimble JM (ed) Cryosols. Springer-Verlag, Berlin Heidelberg, pp 365-390

Van Vliet-Lanoë B, Magyari A, Meilliez F (2004b) Distinguishing between tectonic and periglacial deformations of quaternary continental deposits in Europe. Glob Planet Chang 43:103-127. https://doi. org/10.1016/j.gloplacha.2004.03.003
Walaszczyk I, Remin Z (2015) Kreda obrzeżenia Gór Świętokrzyskich. In: Skompski S, Mizerski W, Ploch I, Konon A (eds) LXXXIV Zjazd Naukowy Polskiego Towarzystwa Geologicznego, Chęciny, 9-11 września 2015 r. Ekstensja i inwersja powaryscyjskich basenów sedymentacyjnych. Państwowy Instytut Geologiczny Państwowy Instytut Badawczy, Warszawa, pp 41-50

Whallon R (2006) Social networks and information: Non-"utilitarian" mobility among huntergatherers. J Anthropol Archaeol 25:259-270

Winiarska-Kabacińska M (2014) Feminine flint plaquettes. a functional perspective. In: Wilczyce SR (ed) A late Magdalenian winter hunting camp in southern Poland. Institute of Archaeology and Ethnology Polish Adacemy of Sciences, Warszawa, pp 319-333

Wiśniewski T (2008) Krzemień czekoladowy w inwentarzach kręgu magdaleńskiego na ziemiach polskich. In: Borkowski W, Libera J, Sałacińska B, Sałaciński S (eds) Krzemień czekoladowy w pradziejach. Materiały z konferencji w Orońsku, 08-10.10.2003. Studia nad gospodarką surowcami krzemiennymi w Pradziejach 7: 137-150.

Wiśniewski T (2015) Magdalenian settlement in Klementowice. In: Klementowice WT (ed) A Magdalenian site in eastern Poland. Institute of Archaeology Maria Curie-Skłodowska University in Lublin, Lublin, pp 15-179

Wiśniewski T (2020) Stare Baraki. A new Magdalenian site in eastern Poland. Anthropol-Int J Human Divers Evol LVIII/2-3:303-320. https://doi.org/10.26720/anthro.20.06.12.2

Wiśniewski A, Furmanek M, Borowski M, Kądziołka K, Rapiński A, Winnicka K (2012a) Lithic raw material and Late Palaeolithic strategies of Mobility: a case study from Sowin 7, SW Poland. Anthropol - Int J Human Divers Evol L/4:391-409

Wiśniewski T, Mroczek P, Rodzik J, Zagórski P, Wilczyński J, Nývltová Fišáková M (2012b) On the periphery of the Magdalenian World. An open-air site in Klementowice (Lublin Upland, Eastern Poland). Quat Int 272-273:308-321

Wiśniewski A, Połtowicz-Bobak M, Bobak D, Jary Z, Moska P (2017) The Epigravettian and the Magdalenian in Poland: new chronological data and an old problem. Geochronometria 44:16-29. https:// doi.org/10.1515/geochr-2015-0052

Włodek M, Gaździcka E (2009) Objaśnienia Do Szczegółowej Mapy Geologicznej Polski 1: 50 000, Arkusz Annopol (820). Państwowy Instytut Geologiczny Państwowy Instytut Badawczy, Warszawa

Złonkiewicz Z (1994) Objaśnienia do Szczegółowej Mapy Geologicznej Polski 1:50 000, arkusz Ożarów. Państwowy Instytut Geologiczny, Warszawa, p 819

Publisher's note Springer Nature remains neutral with regard to jurisdictional claims in published maps and institutional affiliations. 